\title{
Assessment of Potential Flood Events and Impacts at INL's Proposed Remote-Handled Low-Level Waste Disposal Facility Sites
}

September 2010

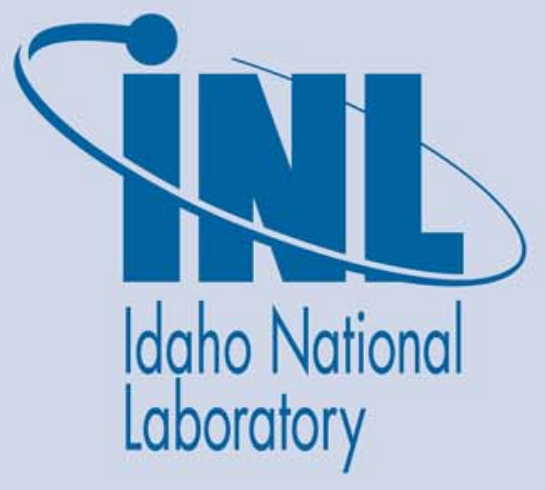

The INL is a U.S. Department of Energy National Laboratory operated by Battelle Energy Alliance 


\section{DISCLAIMER}

This information was prepared as an account of work sponsored by an agency of the U.S. Government. Neither the U.S. Government nor any agency thereof, nor any of their employees, makes any warranty, expressed or implied, or assumes any legal liability or responsibility for the accuracy, completeness, or usefulness, of any information, apparatus, product, or process disclosed, or represents that its use would not infringe privately owned rights. References herein to any specific commercial product, process, or service by trade name, trade mark, manufacturer, or otherwise, does not necessarily constitute or imply its endorsement, recommendation, or favoring by the U.S. Government or any agency thereof. The views and opinions of authors expressed herein do not necessarily state or reflect those of the U.S. Government or any agency thereof. 


\section{Assessment of Potential Flood Events and Impacts at INL's Proposed Remote-Handled Low-Level Waste Disposal Facility Sites}

September 2010

Idaho National Laboratory Idaho Falls, Idaho 83415

http://www.inl.gov

Prepared for the

U.S. Department of Energy

Office of Nuclear Energy

Under DOE Idaho Operations Office

Contract DE-AC07-05ID14517 



\section{ABSTRACT}

Potential flooding scenarios and impacts have been evaluated for the proposed remote-handled low-level waste disposal facility at the Idaho National Laboratory (INL). The facility is being evaluated as an onsite disposal alternative in anticipation of the need for additional disposal capacity brought on by closure of the Radioactive Waste Management Complex. The purpose of the flood assessment is to provide supporting information for use in the facility performance assessment required by Department of Energy Order 435.1, "Radioactive Waste Management," (and the environmental assessment required by the National Environmental Policy Act [42 USC §4321 et seq.]).

The assessment examined potential water flow rates, water depths, erosion potential, increased subsurface contaminant migration rates, and annual exceedance probabilities for potential sources of flood water, including those arising from (1) local precipitation events, (2) precipitation events occurring off INL (i.e., offsite precipitation), and (3) increased flows in the Big Lost River in the event of a Mackay Dam failure. Onsite precipitation events include potential snow-melt and rainfall. Extreme rainfall events were evaluated for the potential to create local erosion, particularly of the cover that will be placed over the disposal facility after closure. Offsite precipitation carried onto INL by the Big Lost River channel was evaluated for overland migration of water away from the river channel. Offsite precipitation sources evaluated were those occurring in the drainage basin above Mackay reservoir. In the worst-case scenarios, precipitation occurring above Mackay Dam could exceed the dam's capacity, leading to overtopping and eventual dam failure. Mackay Dam also could fail during a seismic event or as a result of mechanical piping. Some of the water released during dam failure and contributing precipitation has the potential of being carried onto INL in the Big Lost River channel. Resulting overland flows from these flood sources were evaluated for their erosion potential, ability to overflow the proposed disposal facility, and ability to increase migration of contaminants from the facility.

The assessment of available literature suggests that the likelihood of detrimental flood water impacting the proposed remote-handled low-level waste facility is extremely low. The annual exceedance probability associated with uncontrolled flows in the Big Lost River impacting either of the proposed sites is $1 \times 10^{-5}$, with an average recurrence interval (return period) of 10,000 years. The most probable dam failure scenario has an annual exceedance probability of $6.3 \times 10^{-6}$ (return period $=1.6 \times 10^{5}$ year). In any of the scenarios generating possible onsite water, the duration is expected to be quite short, water depths are not expected to exceed $0.5 \mathrm{~m}$, and the erosion potential can easily be mitigated by emplacement of a berm (operational period) and an engineered cover (post-closure period). The potential impact on subsurface mobilization of radionuclides was evaluated for a very conservative flooding scenario (water depth $=50 \mathrm{~cm}$, duration $=61$ days, every 500 years). The periodically recurring flood waters were predicted to marginally increase peak radionuclide fluxes into the aquifer by at most a factor of three for non-sorbing radionuclides and to have limited impact on peak radionuclide fluxes into the aquifer for contaminants that do sorb. 


\section{CONTENTS}

ABSTRACT.

ACRONYMS ix

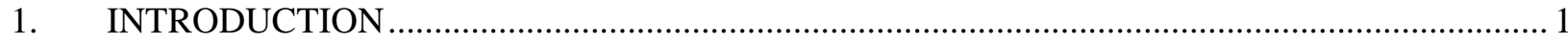

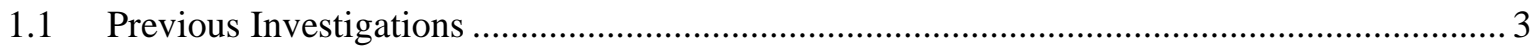

2. OVERVIEW OF THE PROPOSED REMOTE-HANDLED LOW-LEVEL WASTE

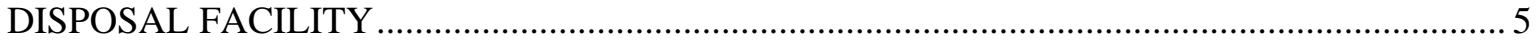

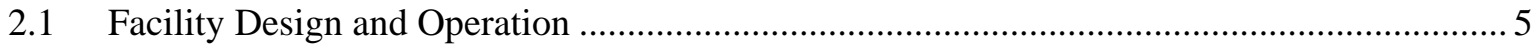

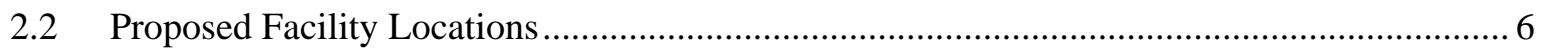

3. FLOOD WATER SOURCES AND FLOODING SCENARIOS …............................................. 7

3.1 Natural (Uncontrolled) Big Lost River Flooding ............................................................. 10

3.1.1 Overview of Paleoflow and Geomorphological Analyses ....................................... 10

3.1.2 Unregulated Flood Annual Exceedance Probability and Return Periods................... 11

3.1.3 Natural Big Lost River Flow Rates, Annual Exceedance Probability, Flood Depth, and Erosion Potential ................................................................................... 11

3.2 Extreme Local Storm Flooding Events ...................................................................... 17

3.3 Probable Maximum Flood with Mackay Dam Failure....................................................... 18

3.3.1 Probable Maximum Precipitation and Mackay Dam Inflow Hydrographs............... 19

3.3.2 Probability of Combined Storm Occurrence ................................................................ 21

3.3.3 Predicted Flow and Duration at the Idaho National Laboratory Diversion Dam and Downstream.......................................................................................... 21

3.4 Seismic Failure of Mackay Dam During a 25-Year Flood ................................................ 22

3.4.1 Probability of Combined Storm and Seismic Event Occurrence ............................... 22

3.4.2 Predicted Flow and Duration at the Idaho National Laboratory Diversion Dam and Downstream

3.5 Hydraulic Piping Failure of Mackay Dam During 100 and 500-Year Floods

3.5.1 Probability of Combined Storm and Hydraulic Piping Failure Occurrence 24

3.5.2 Predicted Flows and Duration at the Idaho National Laboratory Diversion Dam.

3.6 Annual Exceedance Probability and Flooding Summary 25

4. EVALUATION OF PROBABLE FLOODING CONSEQUENCES AT THE PROPOSED REMOTE-HANDLED LOW-LEVEL WASTE DISPOSAL FACILITY SITES 


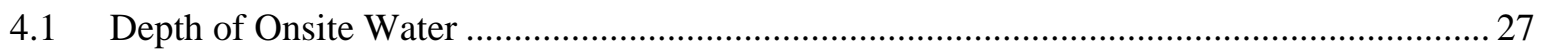

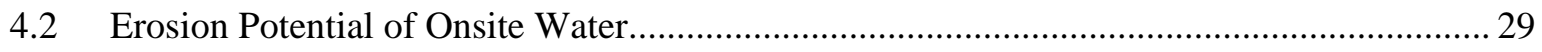

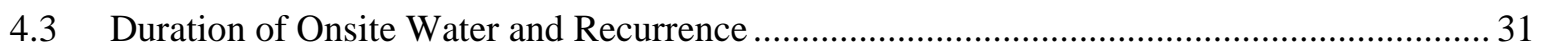

4.4 Subsurface Underflow Induced by Onsite Water............................................................ 31

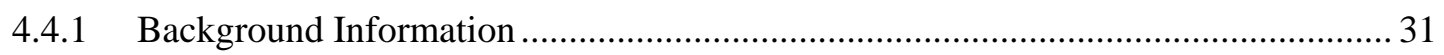

4.4.2 Evaluation of Net Water Resulting from Flooding Scenarios versus Natural

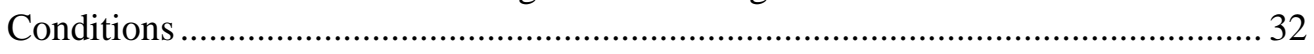

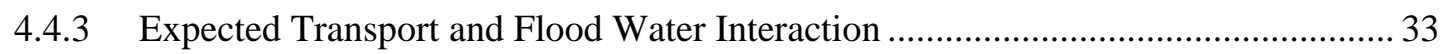

4.4.4 Simulated Transport and Flood Water Interaction................................................... 34

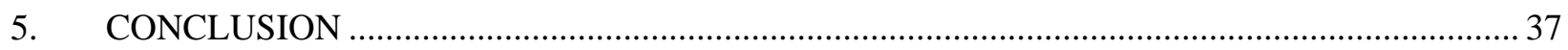

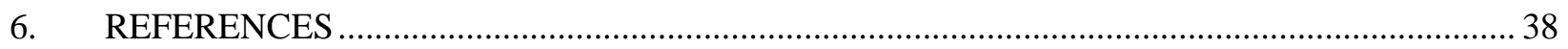

\section{FIGURES}

1. Two highest ranked sites for the proposed remote-handled low-level waste disposal

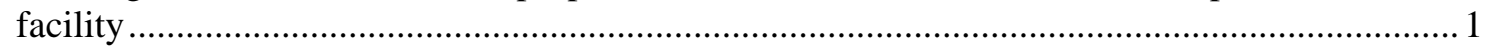

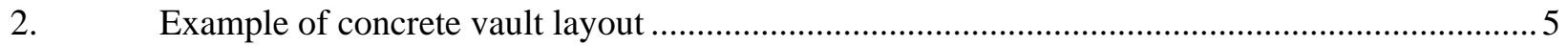

3. Preliminary cover design for the INL RH-LLW Disposal Facility ......................................... 6

4. Soil pit locations for the geomorphic evaluation by Ostenaa et al. (1999)................................ 7

5. Big Lost River drainage basin showing Mackay reservoir, prominent gaging stations (red triangles), the INL Diversion Dam, and locations of primary facilities near Site 5 (Advanced Test Reactor Complex) and Site 34 (Idaho Nuclear Technology and Engineering Center).

6. Annual peak discharge estimates on the Big Lost River upstream and downstream of Mackay Reservoir.

7. Peak discharges as a function of return period and annual exceedance probability flows in the Big Lost River at the INL Diversion Dam....

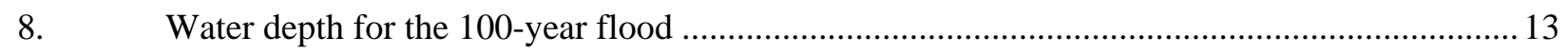

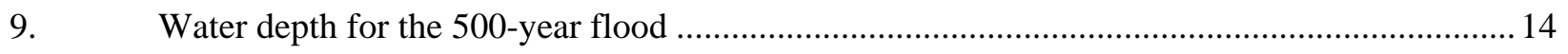

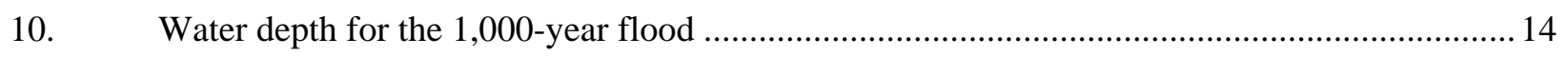

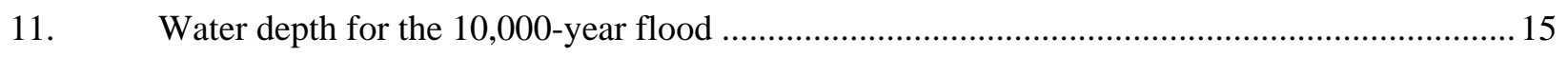

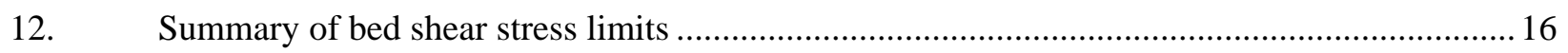


13. Bed shear stress near the Idaho Nuclear Technology and Engineering Center and the Advanced Test Reactor Complex facilities for the 20,000-year flood.

14. One hour, $1-\mathrm{mi}^{2}$ local storm probable maximum precipitation in inches for elevations to $6,000 \mathrm{ft}$.

15. 24-hour, $10-\mathrm{mi}^{2}$, general storm probable maximum precipitation in inches

16. Discharge hydrographs for the probable maximum flood-induced dam failure.....

17. Discharge hydrographs for the seismically induced dam failure.

18. Comparison of estimated peak flow rates at the Idaho National Laboratory Diversion Dam for different flood scenarios

19. Water depth for the 1,902-cms flow rate at the INL Diversion Dam

20. Bed shear stress near Idaho Nuclear Technology and Engineering Center and Advanced Test Reactor Complex facilities for the 1,902-cms flow rate at the INL Diversion Dam

21. Net infiltration water flux below the waste and water flux at the vadose zone-aquifer interface.

22. Radionuclide flux as a function of time at the vadose zone-aquifer interface for a radionuclide with a distribution coefficient of zero $\mathrm{mL} / \mathrm{g}$..

23. Radionuclide flux as a function of time at the vadose zone-aquifer interface for a radionuclide with a distribution coefficient of $2 \mathrm{~mL} / \mathrm{g}$.

24. Radionuclide flux as a function of time at the vadose zone-aquifer interface for a radionuclide with a distribution coefficient of $6 \mathrm{~mL} / \mathrm{g}$.

\section{TABLES}

1. Mean natural (uncontrolled) peak flows at the Idaho National Laboratory Diversion

Dam ......

2. Mean natural (uncontrolled) peak flows at INL Diversion Dam, including the assessments of the probable maximum flood and other dam failure scenarios

3. Geomorphic soil ages near proposed Site 5 and Site 34 .

4. Net volume of water per unit of cross-sectional area for natural and 500-year flood conditions

5. Lithology description for flooding scenario analysis 


\section{ACRONYMS}

AEP annual exceedance probability

ATR Advanced Test Reactor

CERCLA Comprehensive Environmental Response Compensation and Liability Act

cfs cubic feet per second

cms cubic meters per second

DOE Department of Energy

ICDF INL CERCLA Disposal Facility

INL Idaho National Laboratory

INTEC Idaho Nuclear Technology and Engineering Center

PMF probable maximum flood

PMP probable maximum precipitation

RH-LLW remote-handled low-level waste

TAN Test Area North 


\section{Assessment of Potential Flood Events and Impacts at INL's Proposed Remote-Handled Low-Level Waste Disposal Facility Sites}

\section{INTRODUCTION}

Since 1952, all remote-handled low-level waste (RH-LLW) generated at Idaho National Laboratory (INL) has been disposed of at the Subsurface Disposal Area of the Radioactive Waste Management Complex. In anticipation of closure of the Radioactive Waste Management Complex, INL is considering a new RH-LLW disposal facility as part of an onsite disposal alternative. According to Harvego et al. (2010), the two highest ranked candidate locations for the proposed disposal facility are (1) southwest of the Advanced Test Reactor (ATR) Complex (Site 5) and (2) southwest of the Idaho Nuclear Technology and Engineering Center (INTEC) at INL (Site 34) (see Figure 1). These sites are similar demographically and climatographically. They are both located near the ephemeral Big Lost River and are roughly equidistant (about $450 \mathrm{ft}$ ) above the underlying Snake River Plain Aquifer.

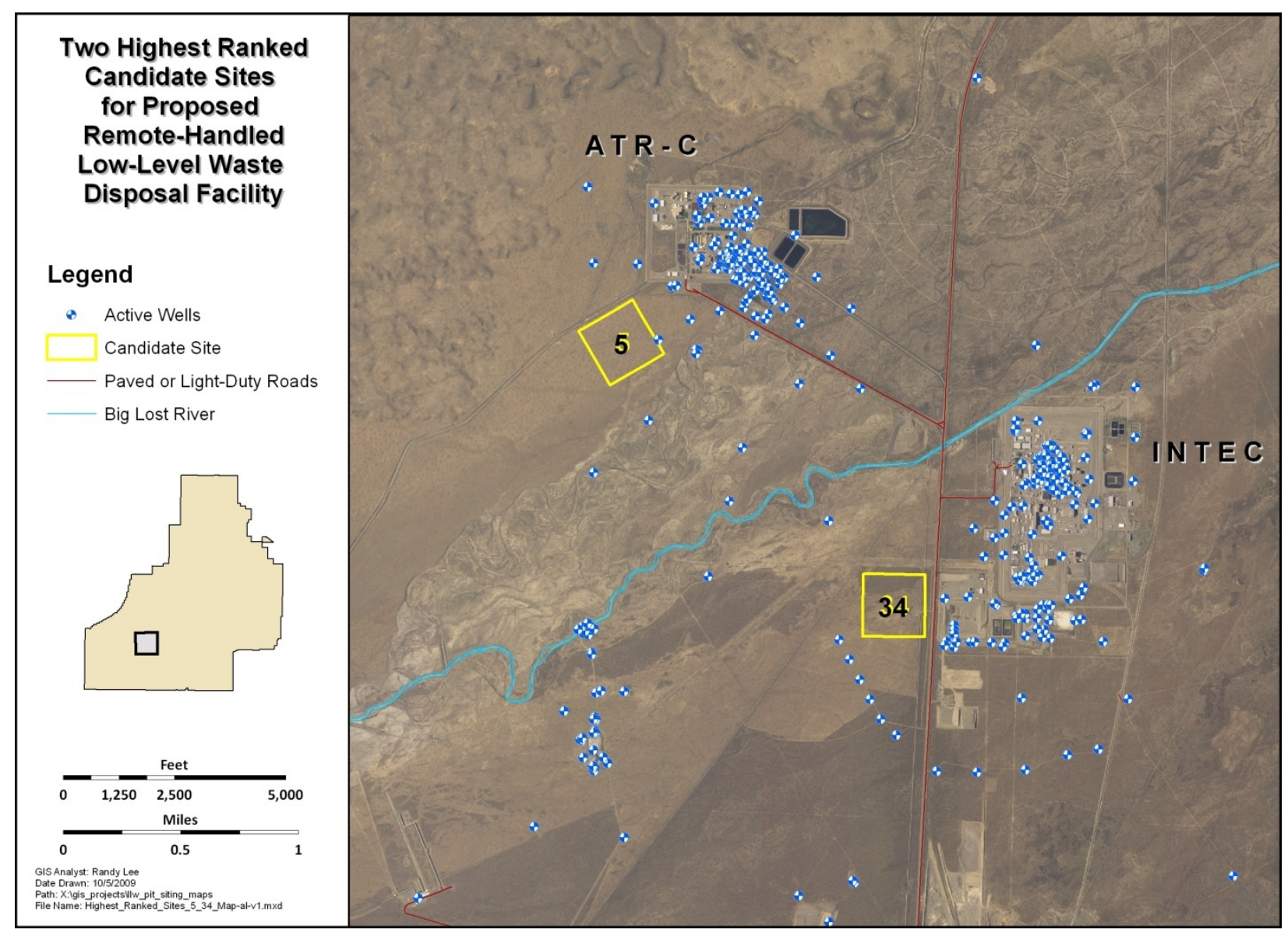

Figure 1. Two highest ranked sites for the proposed remote-handled low-level waste disposal facility. The proposed facility will occupy 5 acres within the outlined 45-acre areas.

Design and operation of the proposed RH-LLW disposal facility must consider potential adverse impacts caused by flood water. Potential sources of water include those from (1) onsite local precipitation events, (2) precipitation events occurring off INL (i.e., offsite precipitation), and (3) increased flows in the Big Lost River in the event of a Mackay Dam failure. Onsite local precipitation events include 
potential snow-melt and rainfall. Extreme rainfall events could result in local erosion, particularly of the cover that will be placed over the disposal facility after closure. Offsite precipitation would be carried onto INL by the Big Lost River channel, which, given high-enough flows, could result in overland migration of water away from the river channel. Offsite precipitation sources of concern would primarily occur above Mackay Dam. In the worst-case scenarios, precipitation occurring above Mackay Dam could exceed the dam's capacity, leading to overtopping and eventual dam failure. Mackay Dam also could fail during a seismic event or as a result of mechanical piping. Some of the water released during dam failure and contributing precipitation has the potential of being carried onto INL in the Big Lost River channel. Resulting overland flows from any of these flood sources must be evaluated for their erosion potential, ability to overflow the proposed disposal facility, and ability to increase release and migration of contaminants from the facility.

The ability of these potential flood water sources to impact facility design and long-term facility performance will vary depending on site location, operational controls in place, source water volume, erosion potential, and onsite duration of surface water. The information presented is provided to assess the likelihood and potential impact of each of the significant sources of flood waters. The purpose of this assessment is to provide supporting information for use in the facility performance assessment required by Department of Energy (DOE) Order 435.1, “Radioactive Waste Management," (DOE-O 435.1 2001) and the environmental assessment required by the National Environmental Policy Act (42 USC §4321 et seq.).

In order to put the potential impacts of flooding into perspective for the proposed RH-LLW disposal facility, key aspects of facility design will be reviewed in Section 2. This material is meant to provide an overview of the waste form and controls in place during key time periods to prevent flooding and to illustrate the facility locations relative to the potential sources of flood waters. Section 3 contains a discussion of flood water sources and flooding scenarios based on a review of previous extensive analyses of possible precipitation events and channel flows. Of particular importance are the probabilities of occurrence of these natural precipitation events in addition to their duration and magnitude. The flood water sources are discussed in order of the following:

- Uncontrolled (natural) flooding of the Big Lost River - Section 3.1 reviews evaluation of historically derived discharge rates for flows in the Big Lost River on INL. This section also contains a review of annual exceedance probability calculations and presents the most current estimates of natural flow peak discharges at the INL Diversion Dam as a function of annual exceedance probability.

- Extreme local flooding caused by local storm events leading to runon/off - Section 3.2 presents an evaluation of onsite precipitation events that could occur at the RH-LLW facility locations, leading to onsite flooding. These events would occur during a local probable maximum precipitation (PMP) event on INL. The annual exceedance probability for this event also is discussed.

- Probable maximum flood (PMF) with Mackay Dam failure - Section 3.3 presents an evaluation of flood waters that would result from precipitation upstream of the Mackay Dam, potentially overtopping Mackay Dam, leading to its ultimate failure. An (1) evaluation of the offsite PMP event that could occur in the drainage basin of Mackay Dam and (2) the resulting PMF that would occur if Mackay Dam failed are reviewed. As evaluated in this section, the annual exceedance probability is computed from the combined probabilities and likelihoods of multiple events occurring simultaneously.

- $\quad$ Seismic failure of Mackay Dam during the 500-year flood - Section 3.4 reviews flood waters that would be expected at INL when released from Mackay Dam as a result of a potential seismic event causing the failure of Mackay Dam. This is a multiple-event occurrence, where the dam is assumed to fail during the 500-year off-site PMP. As a result, the annual exceedance probability is much less than the probability of either event occurring independently. 
- $\quad$ Piping failure of Mackay Dam during a 25-year flood - Section 3.5 reviews the predicted flood waters at INL that would be released during a potential hydraulic piping failure of Mackay Dam. This event is more likely to occur than either of the other two Mackay Dam failure scenarios and is accompanied by the 25-year offsite PMP event. As with the other dam failure events evaluated, the annual exceedance probability is presented for the concurrent storm and piping failure.

Section 4 contains an evaluation of the consequences of flooding. Flooding consequences are largely independent of the specific source of flood water and are measured in terms of the potential to damage a facility or to increase contaminant transport from the facility. Damage can be caused by erosion. Increased contaminant transport can be caused by excessive infiltration or long-term infiltration. The following impacts considered in this assessment are presented in terms of onsite water:

- $\quad$ Depth - Depth is used as a surrogate for hydraulic driving force or infiltration and, additionally, was evaluated for potential to contribute to erosion.

- $\quad$ Erosion potential - Erosion potential is quantified in terms of bed shear stress. Bed shear stress has been correlated to movement of soils on terrace surfaces, erosion of upper terrace deposits, and to significant geomorphic channel change.

- Duration - The duration that onsite water impacts total (net) infiltration of ponded water and can influence erosion.

- Subsurface underflow - Underflow of infiltrating water has the potential to mobilize contaminants. The amount of increased mobilization is, in part, a function of ponded water depth and duration and is very much influenced by the return period for presumed flooding events.

\subsection{Previous Investigations}

Water resources of the Big Lost River have been extensively studied by the U.S. Geological Survey, U.S. Army Corps of Engineers, U.S. Department of Agriculture, DOE, and several universities over the past 100 years. These studies were motivated by the need to understand the Mackay Reservoir drainage basin and the Big Lost River for the purposes of assessing irrigation water supply and flooding potential. Of particular interest to this analysis are the investigations focusing on flooding and the probability of flooding in the Big Lost River Basin. These investigations include analyses of historical flooding and antecedent conditions in the basin leading to major flood events (U.S. Army Corps of Engineers 1967) and the examination of hydrologic effects of flooding arising from a hypothetical failure of Mackay Dam (Carrigan 1972, Druffel et al. 1979, Noble 1980, and Koslow and Van Haaften 1986). The Carrigan (1972) study was conducted to analyze the impact of flood control systems, including culverts for natural flows with relatively short-return periods. Druffel et al. (1979) calculated the properties and route of the flood wave resulting from a hypothetical failure of Mackay Dam. The flood wave time of travel, duration of flooding, and magnitude of the flood were determined for several sites from the dam downstream to the INL Diversion Dam. Noble (1980) extended the results of Druffel et al. (1979) and calculated the flood potential at the Radioactive Waste Management Complex. Noble (1980) estimated that the flood would reach the Radioactive Waste Management Complex about 10 hours after the dam break, with the peak arriving in 12.6 hours resulting in a maximum water depth at of $0.75 \mathrm{~m}$. Koslow and Van Haaften (1986) evaluated coincident scenarios, including seismically induced failure, piping failure, and storm-induced failure of Mackay Dam with results calculated for sites downstream of the INL Diversion Dam. Upper estimates of attenuated peak flows resulting from a failure of Mackay Dam ranged from 45,000 cfs (Koslow and Van Haaften 1986) to about 53,000 cfs (Druffel et al. 1979) at the INL diversion dam, with both studies applying the same DAMBRK model.

Differences in model parameterization between the Druffel et al. (1979) and Koslow and Van Haaften (1986) studies were significant, even though they resulted in a relatively narrow range of predicted discharges. The Druffel et al. (1979) model was based on geometry interpolated between four cross-sections, an assumed INL Diversion Dam capacity of $62 \mathrm{cms}(2,189 \mathrm{cfs})$, a base channel flow of 
$85 \mathrm{cms}$ (3,002 cfs), and a full breach scenario. Their peak predicted depth above the INL Diversion Dam was $2.8 \mathrm{~m}(9.1 \mathrm{ft})$, with the flood arrival time estimated to be 6.1 hours, peaking in 10.6 hours. Druffel et al. (1979) did not expand their evaluation beyond the base flow of $85 \mathrm{cms}$ (3,002 cfs) and did not predict flood inundation below the INL diversion.

In contrast, the Koslow and Van Haaften (1986) model was based on 45 cross-sections interpolated linearly to form a total of 259 cross-sections. A higher INL diversion capacity of $203.9 \mathrm{cms}(7,200 \mathrm{cfs})$ was incorporated, with an additional $59.5 \mathrm{cms}(2,100 \mathrm{cfs})$ capacity provided by low swales southwest of the main channel for a total diversion capacity of $263.4 \mathrm{cms}$ (9,300 cfs). Base flow in the Big Lost River was assumed to be $30.6 \mathrm{cms}$ (1,082 cfs), roughly equal to the average mean monthly flow for June 1.6 miles below Mackay Dam. Additionally, the probable maximum precipitation event occurring coincident with the dam breach was assumed to provide a total of $16.83 \mathrm{~cm}$ (5.13 in) of water in 48 hours. Predicted peak water depth at the INL diversion was $8.3 \mathrm{~m}(27 \mathrm{ft})$, with the flood waters arriving in 11.8 hours. In addition to providing estimated discharges at the INL diversion for the probable maximum flood (PMF) scenario, Koslow and Van Haaften (1986) also provided estimates for three other scenarios including 1) a 25-year precipitation event coincident with a seismically induced failure of MacKay dam, 2) a 100-year precipitation event coincident with hydraulic piping induced failure of MacKay Dam, and 3) a 500-year precipitation event coincident with hydraulic piping induced failure of MacKay Dam. Their simulations were extended below the INL diversion to provide flood inundation near key INL facilities.

The spatial extent of flooding has also been extensively investigated, providing stage-discharge relations for the reaches of the Big Lost River on INL. Approaches include application of 1) the WSPRO model (Bennett 1986, Berenbrock and Kjelstrom 1998, and Downs et al. 1999) to compute water-surface profiles, assuming one-dimensional, gradually-varied, steady flow; 2) the HEC-6 and HEC-RAS models to incorporate sediment transport and scouring in one-dimension (Berenbrock et al. 2007); and 3) the TRIM2D model to expand the dimensionality of the flow system, allowing determination of flow conditions necessary to produce overtopping and erosion of the terrain extending beyond the river channel (Ostenaa et al. 1999, Ostenaa and O'Connell 2005). A detailed comparison of the HEC-6 and HEC-RAS model results to the 1999 TRIM2D model results was provided by Berenbrock et al. (2007). Conclusions of that comparison suggested the topographic data used in the 1999 TRIM2D model were insufficiently detailed, producing simulation results that differed significantly from the HEC-6 and HEC-RAS model results. The topographic details were addressed in the later Ostenaa and O’Connell (2005) report, providing more consistent base model parameterization between the two simulation approaches. In addition to providing model comparisons, Berenbrock et al. (2007) estimated the peak discharge required to develop observed paleo features observed in geomorphic trenches downgradient of the INL Diversion Dam on the Big Lost River. These discharge rates, in combination with U.S. Geological Survey stage data were used to develop flood flow frequency relationships using the approach outlined in Bulletin \#17B (Interagency Advisory Committee on Water Data 1982) out to 500 years. In contrast, a Bayesian flood frequency analysis using maximum likelihood methodology was taken by Ostenaa and O’Connell (2005). Used with paleohydrologic bounds derived through the geomorphic trench data and their two-dimensional model, the approach resulted in estimated peak discharge rates as a function of annual exceedance probability out to 10,000 years. In addition to flood frequencies, both models were used to estimate erosion potential and water depth within the reach spanned by the geomorphic trenches. The model of Ostenaa and O'Connell (2005) was extended downgradient of the geomorphic trench area to include INTEC, the ATR Complex, and Test Area North (TAN); however, the Berenbrock et al. (2007) model only extended through the geomorphic trench reach.

In total, the extensive work conducted by the various agencies has provided sufficient background information to assess the potential flood events and impacts at INL's proposed RH-LLW Disposal Facility Sites. Thus, the assessment provided in this document is based on the combined data and results from available literature. 


\section{OVERVIEW OF THE PROPOSED REMOTE-HANDLED LOW-LEVEL WASTE DISPOSAL FACILITY}

The INL RH-LLW waste facility must meet the requirements of DOE Order 435.1. These requirements include meeting performance objectives (e.g., minimum dose and releases) through the 1,000-year compliance period in addition to considering reasonably foreseeable natural processes that might disrupt the intended performance of the facility. The proposed facility will achieve these objectives through engineered design of waste containment, post-operational closure, and site selection. Key aspects relative to assessment of natural phenomena flooding are reviewed in the following subsections.

\subsection{Facility Design and Operation}

According to the Conceptual Design Report (Harvego et al. 2009), the proposed INL RH-LLW disposal facility will accept two primary types of RH-LLW: activated metals and ion-exchange resins. The activated metals are generated by ATR operations, Naval Reactors Facility operations, and from processing waste stored in the Radioactive Scrap and Waste Facility at the Materials and Fuels Complex. The metal and resin waste will be contained in sealed and vented liners made of steel. The liners will be placed in concrete disposal vaults at the disposal facility. The disposal vaults will be constructed as precast concrete cylinders (i.e., pipe sections) stacked on end and placed in a close-packed array as shown in Figure 2. All vaults will be supported by reinforced concrete base sections placed atop a gravel layer, and covered with removable hexagonal precast concrete plugs. The plugs serve as a radiation shield for emplaced waste and act as a water barrier to prevent water from entering the vaults. The area around the vaults will be backfilled with sand for stability and to promote drainage away from the facility.

During the 2016 through 2065 operational period, the containers and vaults will provide sufficient barriers from water and air such that negligible transport of contaminants into the environment will occur. At the end of the operational period, the disposal facility will be closed.

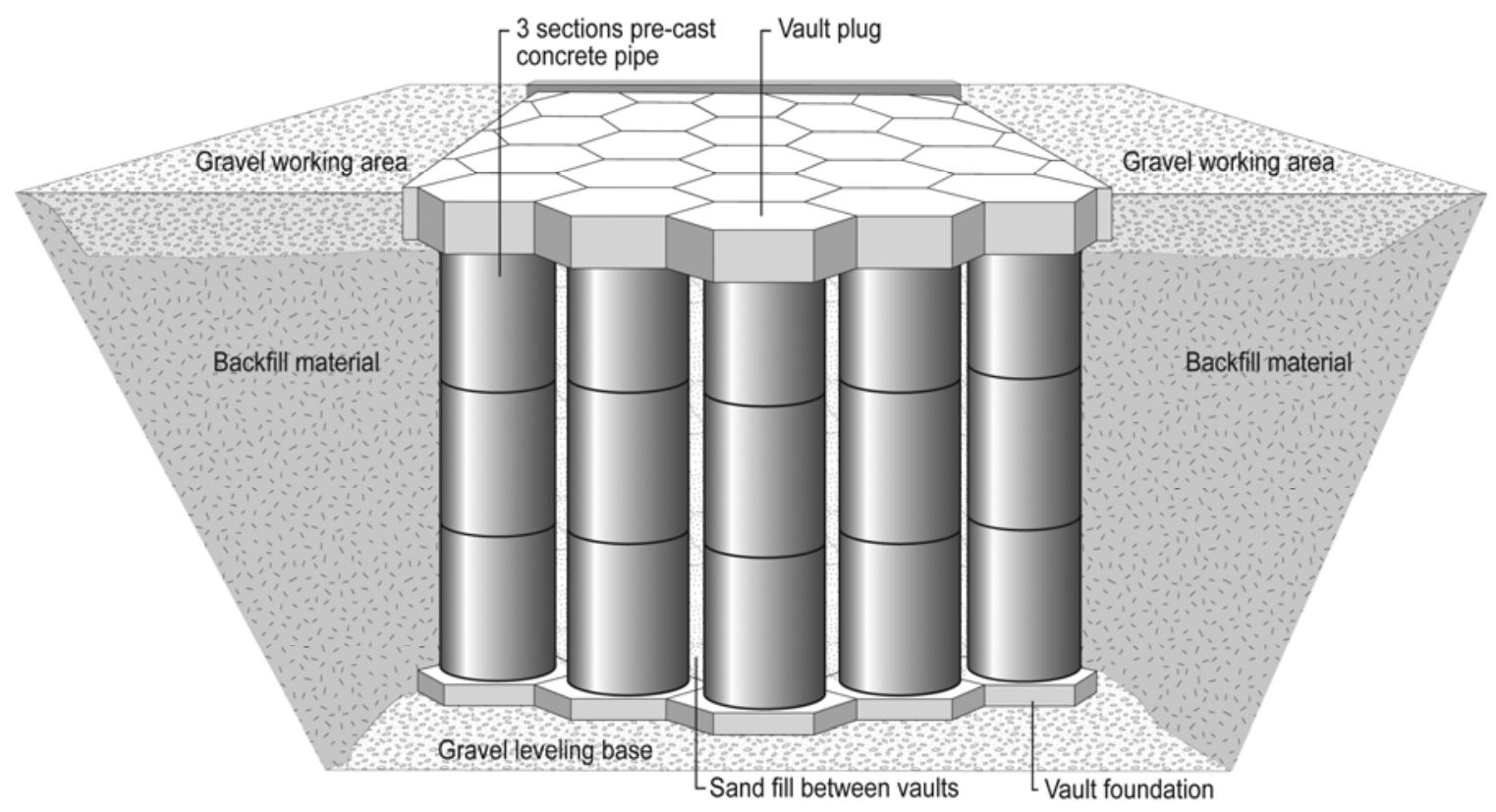

Figure 2. Example of concrete vault layout (Harvego et al. 2009).

At the end of the operational life of the disposal facility, a protective cover will be placed over the waste disposal vaults (Figure 3). The primary purposes of the cover are to (1) minimize infiltration into the disposal facility after facility closure, thus reducing leachate generation and contaminant transport, and (2) provide a barrier against intrusion. In addition to infiltration and intrusion limiting features, the 
cover will include armoring on the sides to prevent wind and rain erosion. The cover will be configured to divert surface water away from the vaults and extend beyond the boundary of the facility. The cover dimensions, layer thicknesses, and other specifications will be determined prior to facility closure and be based on the final size and configuration of the facility. The cover also will incorporate criteria identified in the facility performance assessment.

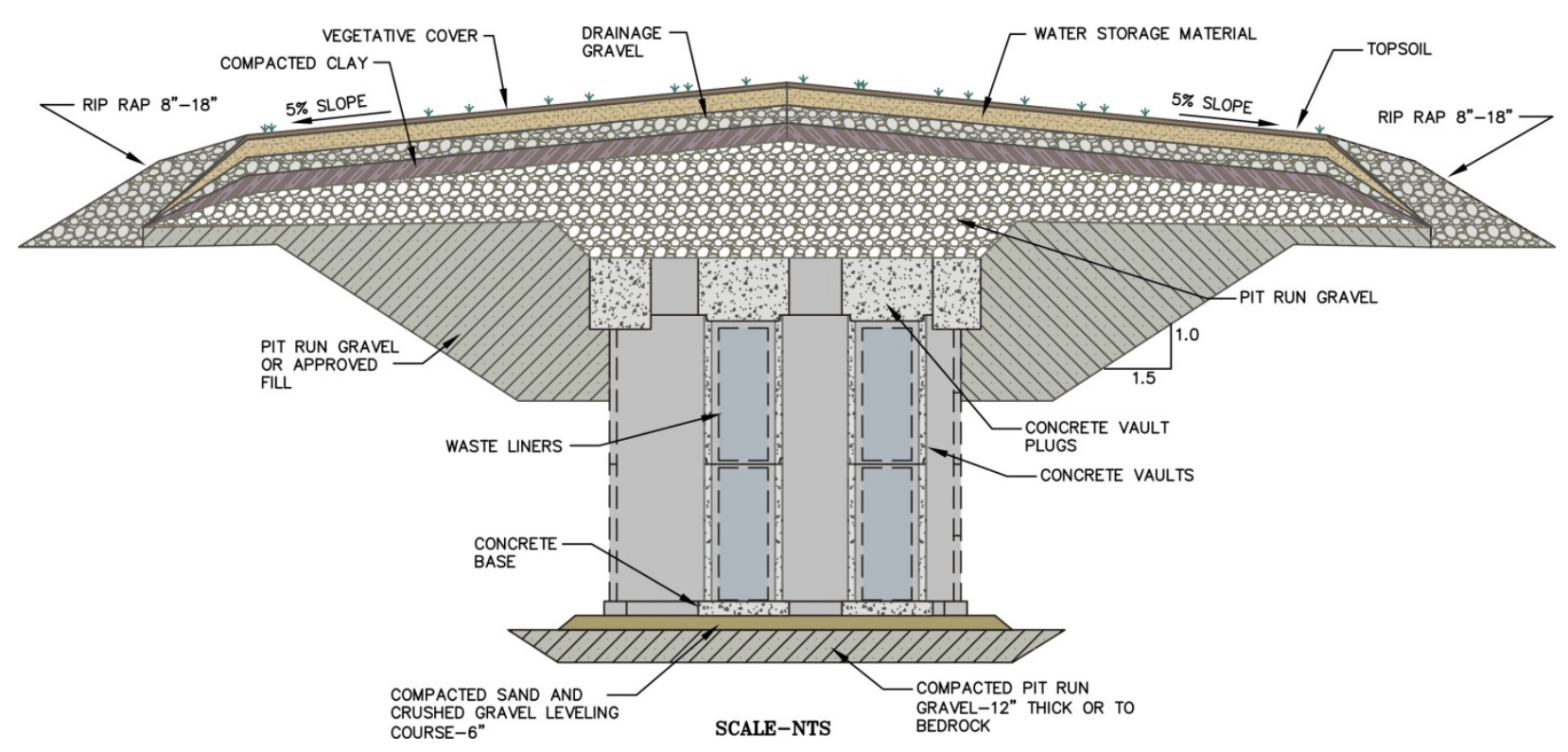

Figure 3. Preliminary cover design for the INL RH-LLW Disposal Facility.

\subsection{Proposed Facility Locations}

Candidate sites for the proposed disposal facility were identified through a rigorous selection process documented in Harvego et al. (2010). Locations of the two highest ranking sites (Sites 5 and 34) are near existing facilities at INL with Site 5 located southwest of the ATR Complex and Site 34 located near ICDF, which is south of INTEC. The hydrogeology of both of these sites has been extensively evaluated. The following information is relevant to the evaluation of flood water potential:

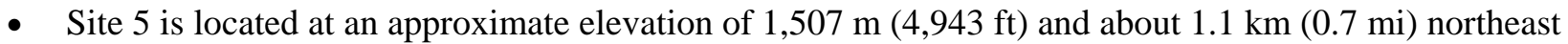
of the Big Lost River channel. An evaluation of the ATR Complex geomorphic setting, based on soil profiles BOR9 through BOR15 (see Figure 4), indicates that this location is on geomorphic surfaces that are well in excess of 10,000 years in age (Ostenaa et al. 1999).

- Site 34 is located at an approximate elevation of 1,502 m (4,927 ft) and about $0.6 \mathrm{~km}(0.4 \mathrm{mi})$ southeast of the Big Lost River (see Figure 4). An evaluation of the INTEC geomorphic setting, based on soil profiles taken along the Big Lost River and used to develop a late Quaternary soil chronosequence, indicates that this location is on geomorphic surfaces that are well in excess of 10,000 years in age (Ostenaa et al. 1999).

Soils in pit BOR15 are 1,000 to 3,000 years (1 to $3 \mathrm{ka}$ ) old and are approximately 15 to $30 \mathrm{ka}$ old in pit BOR16. Soil ages are 1 to $3 \mathrm{ka}$ in pit BOR14, 10 to $30 \mathrm{ka}$ in BOR11, and 15 to $50 \mathrm{ka}$ in BOR9 and BOR10. Soil ages at both sites suggest that the hazard of significant flooding of these areas by the Big Lost River is historically low under natural channel conditions. 


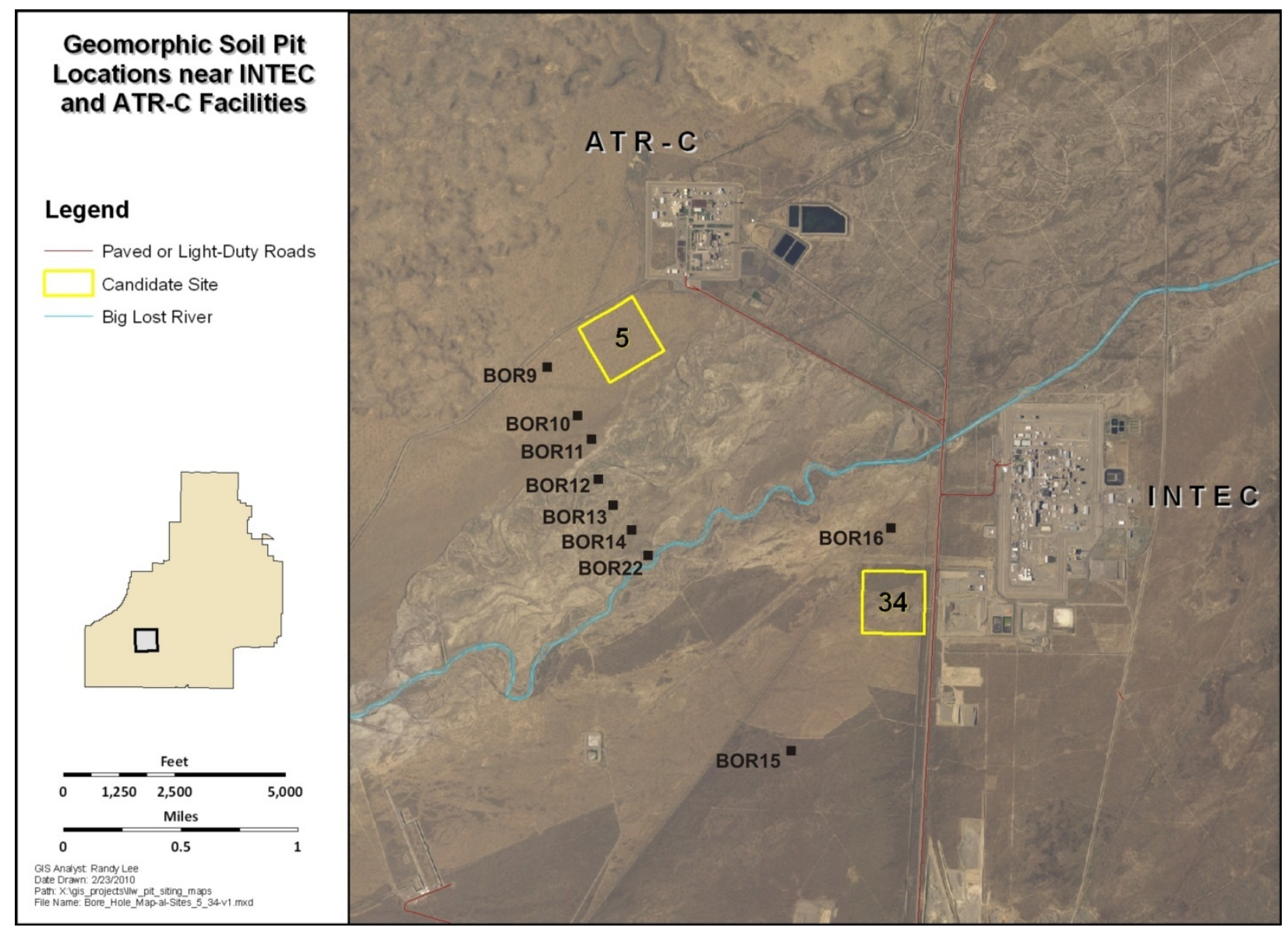

Figure 4. Soil pit locations for the geomorphic evaluation by Ostenaa et al. (1999). Yellow rectangles represent 45-acre areas. The proposed facility will occupy 5 acres within the outlined 45-acre area.

\section{FLOOD WATER SOURCES AND FLOODING SCENARIOS}

This section presents an evaluation of flood water sources for several different scenarios leading to flood water potentially reaching the proposed facility locations. The most likely source of floodwaters for the facility is the Big Lost River. The Big Lost River is the major surface water feature on the INL site. The headwaters of the Big Lost River are in the mountain ranges northwest of INL (see Figure 5). From these ranges, the river flows a distance of about $100 \mathrm{~km}$ (60 miles) through the Big Lost River Valley, an alluvium-filled valley, to the edge of the Snake River Plain near Arco. Downstream of Arco, the river flows onto INL and across the basalt flows of the Snake River Plain before terminating in an area known as the Lost River Sinks.

Control of the Big Lost River occurs upstream of Arco at Mackay Dam and at the INL Diversion dam. Mackay Dam, located about 6.4 km (4 miles) northwest of Mackay, Idaho, is used to control and impound water for irrigation purposes. Between Mackay Dam and the INL Diversion Dam, additional stream flow depletion occurs due to irrigation and infiltration losses along the river. When flow in the Big Lost River actually reaches INL, it is either diverted at the INL Diversion Dam to the Spreading Areas or flows northward across INL in a shallow, gravel-filled channel before terminating at the Lost River Sinks. 


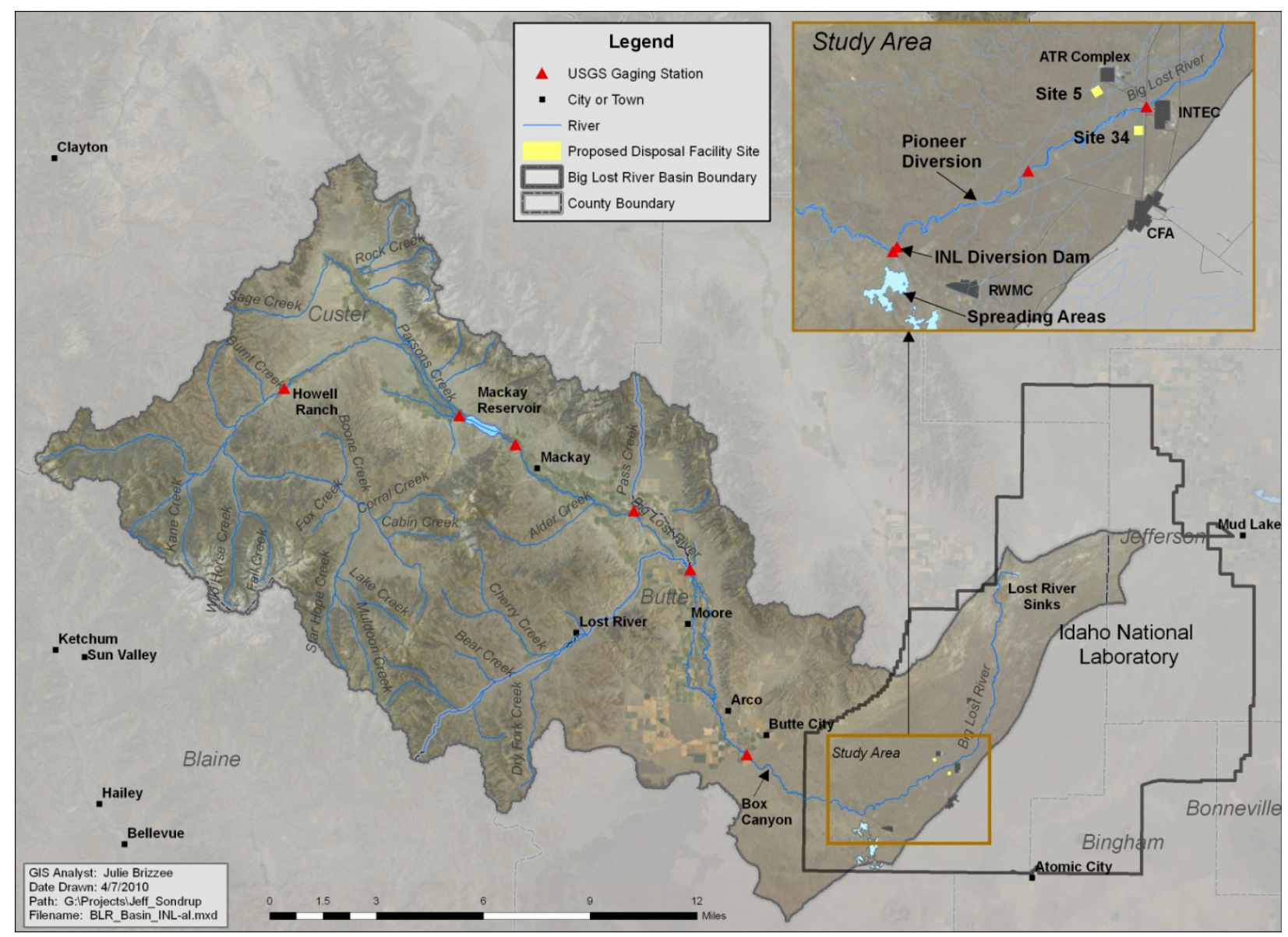

Figure 5. Big Lost River drainage basin showing Mackay reservoir, prominent gaging stations (red triangles), the INL Diversion Dam, and locations of primary facilities near Site 5 (Advanced Test Reactor Complex) and Site 34 (Idaho Nuclear Technology and Engineering Center). The inset area is the study area for the most recent Big Lost River flood studies.

Average annual precipitation in the Big Lost River basin ranges from about $125 \mathrm{~cm} / \mathrm{year}$ in the mountainous upper basin areas to about $20 \mathrm{~cm}$ /year across much of INL. This precipitation occurs mostly in the winter months and is largely derived from moisture from the northern Pacific Ocean (Kjelstrom 1991). Annual stream flows are dominated by spring and early summer snowmelt and runoff from the mountains in the upper drainage basin. Snowmelt is regular, usually beginning in late May or early June of each year, with significant flows extending into July.

Annual peak discharge estimates in the Big Lost River for an upstream gaging station at Howell Ranch are shown in Figure 6 (light-shaded bars) for the 1904 to 1998 period. Peak discharge rates range from 20 to $125 \mathrm{cms}$ near Howell Ranch. High peak flows associated with snowmelt and low flows occurring during the dry and/or frozen seasons both exhibit small variation year-to-year. Peak discharge estimates from gaging stations near Arco (1947 to 1998) and near Leslie and Moore (1919 to 1926) also are shown in Figure 6 to illustrate the differences that occur along the river. Differences between the upper drainage stream flows and downstream values near Arco are indicative of natural channel infiltration, storage in the Big Lost River Valley, storage in Mackay reservoir, and irrigation diversions upstream of Arco and at the INL site. 


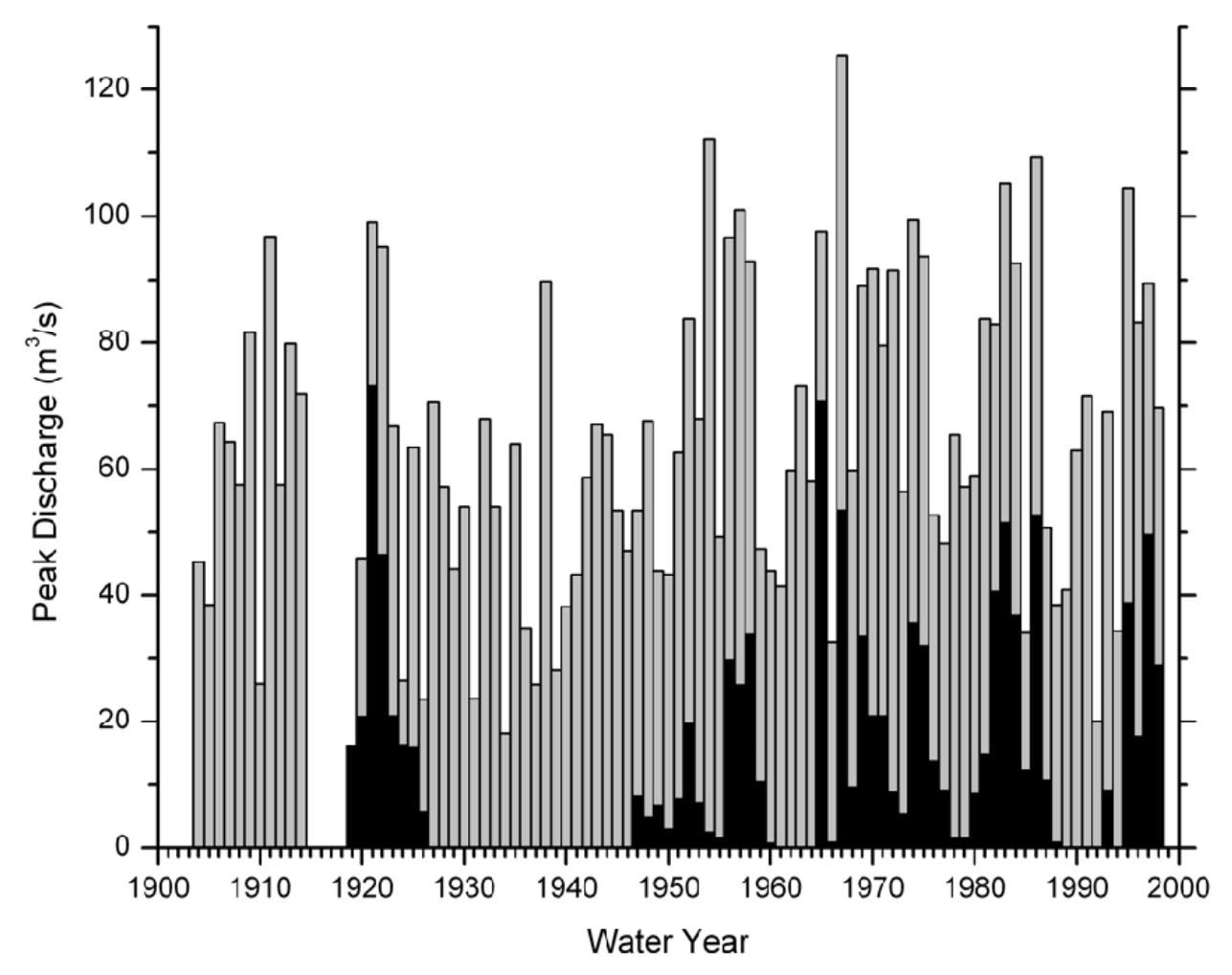

Figure 6. Annual peak discharge estimates on the Big Lost River upstream and downstream of Mackay Reservoir. Upstream estimates (light-shaded bars) are near Howell Ranch and downstream estimates (dark-shaded bars) are from stations near Leslie and Moore (1919 to 1926) and near Arco (1947 to 1998). Peak discharge estimates are not available from the station near Arco for the periods 1905 to 1918, 1927 to 1945, and 1962 to 1964. Figure from Ostenaa and O’Connell (2005).

Given the sources of precipitation and flows on or upgradient of the Snake River Plain, potential sources/scenarios leading to flood water on INL include (1) natural flows in the Big Lost River, (2) extreme precipitation on or near the proposed facility locations, (3) extreme precipitation occurring in the drainage basin of Mackay reservoir causing a Mackay Dam failure, (4) a 25-year precipitation in the Mackay reservoir drainage in combination with the seismic failure of Mackay Dam, and (5) 100 and 500year precipitation in the Mackay reservoir drainage in combination with hydraulic piping failure of Mackay Dam. These significant scenarios have been evaluated in several previous studies with a focus on waters originating offsite precipitated by storm-events occurring upgradient of the INL Diversion Dam, and on those originating onsite during local precipitation events. Key observations and results of these analyses relative to the proposed RH-LLW disposal facility are reviewed in the following sections. They are presented in the numbered order provided in the list above and are based on the references shown in parenthesis below:

- Natural flows in the Big Lost River - These flows are represented in the approximate 100-year historical discharge records of the Big Lost River and are augmented by paleoflow analyses (Ostenaa and O’Connell 2005). Of importance in this section are the flows not controlled by Mackay Dam. 
- Extreme precipitation on or near the proposed facility locations - These events have the potential to create runon/runoff from the facility (DOE-ID 2010). Characterization of the events leading to flooding is provided by the hydrometeorological report (Hansen et al. 1994).

- Probable maximum flood caused by extreme precipitation occurring in the drainage basin of Mackay reservoir leading to failure of Mackay Dam (Koslow and Van Haaften 1986).

- 25-year precipitation in the drainage above Mackay reservoir in combination with a seismic failure of Mackay Dam (Koslow and Van Haaften 1986).

- 100-year and 500-year precipitation event in combination with hydraulic piping failure of Mackay Dam (Koslow and Van Haaften 1986).

\subsection{Natural (Uncontrolled) Big Lost River Flooding}

This section presents an evaluation of rates, rate of recurrence, depths, and erosion potential for the natural flow Big Lost River flooding scenario. This scenario accounts for precipitation-derived flows onto INL that are carried in the Big Lost River and have the potential to reach the proposed facility locations. The Big Lost River is the major surface water feature on the INL Site. The headwaters of the Big Lost River are in the mountain ranges northwest of INL, and, as explained in Section 3, have been controlled downstream of Mackay Dam since it was built in 1918.

Stream flow records are available for a period of 105 years (1904 to present) (see Figure 6) and can be used to correlate measured precipitation to discharge at the INL Diversion Dam during this time period. This record does not include the highest discharges or precipitation events that have occurred through geologic time or that could possibly occur again. The higher discharge rates are evidenced by the paleo record of the Big Lost River channel on INL and have occurred prior to emplacement of Mackay Dam. In the absence of Mackay Dam, they would likely occur again during the 1,000-plus-year performance life of the proposed RH-LLW disposal facility. Because the performance period of interest is much longer than the historical record, the potential impacts of higher-flow discharges have been evaluated.

\subsubsection{Overview of Paleoflow and Geomorphological Analyses}

Unregulated or natural flooding has been evaluated recently by the U.S. Bureau of Reclamation (Ostenaa and O’Connell 2005) and by the U.S. Geological Survey (Berenbrock et al. 2007). Discharge rates and flood frequencies were assessed by Berenbrock et al. (2007) through 500 years, and by Ostenaa and O'Connell (2005) out to 10,000 years. The performance period for the RH-LLW disposal facility is 1,000 years or through the peak arrival of radionuclides in the aquifer, which could be longer. Because of the time period of prediction, the Ostenaa and O'Connell (2005) model results are used in this assessment to determine flood water recurrence and define the Big Lost River flood plain as a function of discharge rate for flows onto INL. Their analysis used a Bayesian flood frequency estimation approach to obtain probabilistic minimum-bias estimates of historical discharge to define probable discharge rates constrained by combined historical and paleoflood data. Paleoflood hydrology is the study of flooddeposited sediments and botanical evidence preserved in rivers and their floodplains. The age of stable geomorphic surfaces adjacent to streams and rivers provides a direct indication of the potential risk of flooding in unregulated or unmodified channel systems (Costa 1978). Paleohydrologic bounds put large historic discharges in their long-term contexts, substantially reducing uncertainty in the range of possible discharges associated with long return periods. Extrapolation for longer return period discharge estimates are in turn bounded by the paleohydrologic analysis by allowing peak discharges with long (i.e., thousands of years) return periods to be directly included in the analysis. 
The major objectives of the Ostenaa and O'Connell (2005) study were focused on two broad technical arenas: (1) geologic, geomorphic, and hydraulic modeling studies to reduce uncertainty associated with paleohydrologic estimates used in flood frequency analyses and (2) developing probabilistic flood stage estimates for specific facility locations at INTEC and the ATR Complex. The paleohydrologic studies included detailed studies of a 5-km (3-mile) reach of the Big Lost River extending between the INL Diversion Dam and the historic Pioneer Diversion (see Figure 5). Geologic data for paleoflood and paleohydrologic bound estimates were derived from seven trenches excavated at three detailed study sites within the study reach. Observations made from geomorphic mapping and trenching data were used in two-dimensional hydraulic models to estimate the extent of paleofloods and paleohydrologic bounds for the Big Lost River. These calibrated models were used to revise and update the unregulated flood frequency analyses for the Big Lost River and were used to predict the extent of inundation as a function of flood water rate passing the INL Diversion Dam.

\subsubsection{Unregulated Flood Annual Exceedance Probability and Return Periods}

In flood hazard analysis, discharge rates are compiled as a function of both the average recurrence interval (return period) and annual exceedance probability (AEP). Figure 7 shows peak discharges as a function of return period and AEP for unregulated natural flows in the Big Lost River at the INL Diversion Dam. The average return period is the average time between exceedances of a given peak flow rate. The AEP is the probability that a given peak flow rate will occur or be exceeded in any one year. A $1 \%$ AEP flow rate has a $1 \%$ (or 1 in 100) chance of occurring or being exceeded in any year. The general relationship between exceedance probability (EP) and average return period (RP) (years) can be written as:

$$
E P=1-\exp \left[\frac{-n}{R P}\right]
$$

Here the exceedance probability is the probability that an event will occur or be exceeded during the time period, $n$ (years). To compute the AEP, $n$ is set equal to 1 year. To compute the probability that the event will be exceeded during the design life of the facility, $n$ is set equal to the design life in years. For average return periods in excess of 10 years, the AEP can be approximated as the reciprocal of the average return period. For example, an average return period of 10,000 years corresponds to an AEP of 0.0001 or $0.01 \%$.

\subsubsection{Natural Big Lost River Flow Rates, Annual Exceedance Probability, Flood Depth, and Erosion Potential}

The peak flows and AEPs at the INL Diversion Dam derived by Ostenaa and O'Connell (2005) are summarized in Table 1 for key time periods. This table contains the time periods (Column 1) corresponding to the AEPs given in Column 2. Columns 3 and 4 contain the peak flow rates shown in Figure 7 in cubic feet per second (cfs) and cubic meters per second (cms), respectively. As explained in Section 3.1.2, the probability of exceeding the peak flow associated with a 10,000-year flood $(279 \mathrm{cms})$ in any year is $0.01 \%$. It is highly unlikely (i.e., $0.005 \%$ ) that the 20,000 -year flow rate $(14,691 \mathrm{cfs})$ will occur as a result of natural flooding events in the Big Lost River. For reference, the 100-year rate (3,072 cfs) shown in Table 1 is comparable to the 3,750 cfs flow published by Hortness and Rousseau (2003) and to the 2,910 cfs flow estimated by Ostenaa et al. (1999). In contrast, a value of $206 \mathrm{cms}$ (7,260 cfs) was estimated by Kjelstrom and Berenbrock (1996) and was discounted as being overly conservative by Hortness and Rousseau (2003). The higher 100-year rate estimated by Kjelstrom and Berenbrock (1996) was contingent on Mackay Reservoir being full, the ground downgradient being saturated, that water would not be diverted into irrigation canals, and that peak flows from each of the subbasins would arrive at the INL simultaneously. 


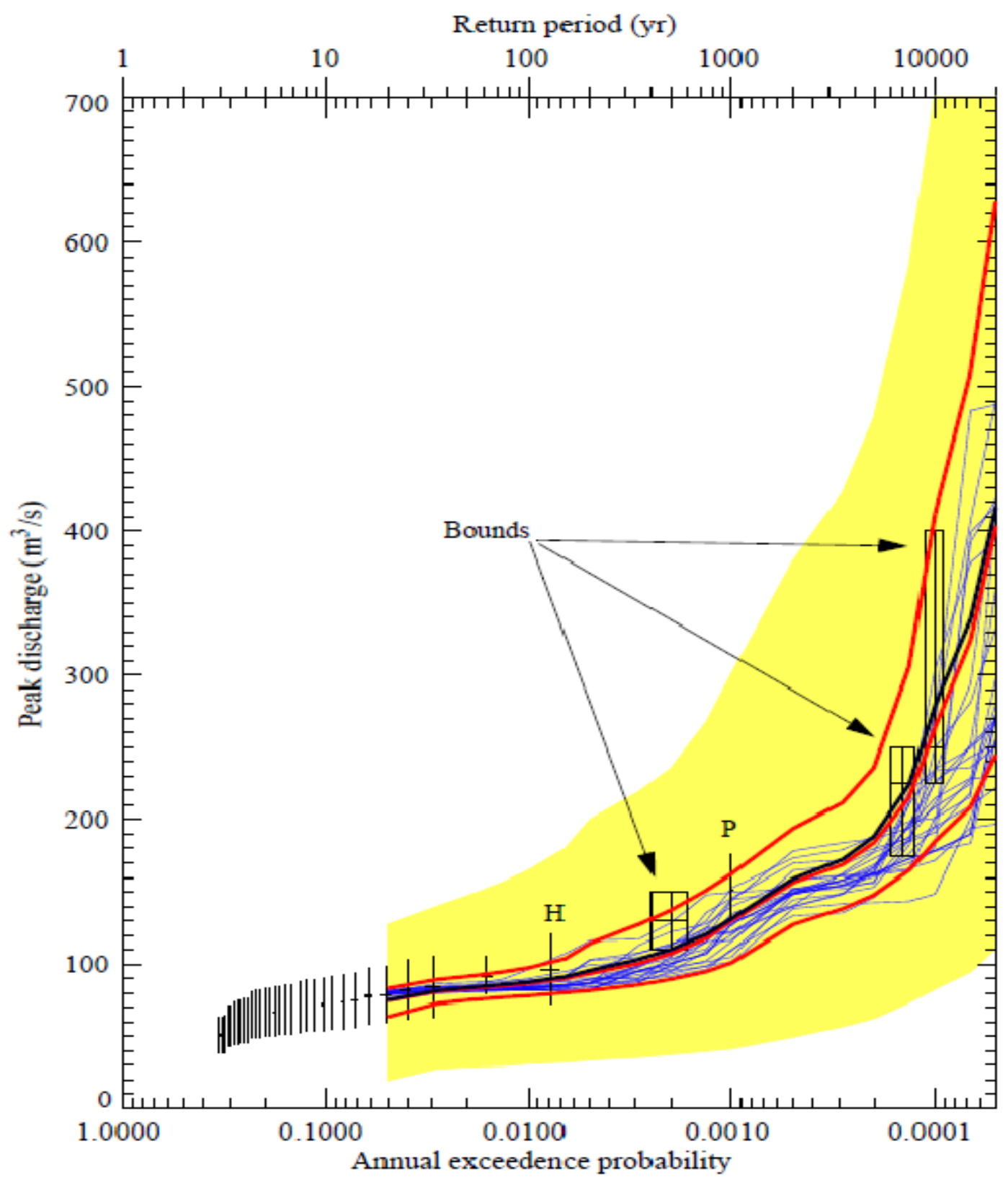

Figure 7. Peak discharges as a function of return period and annual exceedance probability flows in the Big Lost River at the INL Diversion Dam (Ostenaa and O’Connell 2005).

In Figure 7, gauged flows (vertical black lines, with short horizontal lines indicating preferred discharge and plotting position uncertainty) are from the Big Lost River at Howell Ranch (94 years) attenuated to the INL Diversion Dam based on methods of Hortness and Rousseau (2003). The geologic data includes two paleofloods (largest discharges labeled $\mathrm{H}$ and $\mathrm{P}$ ) and three paleohydrologic bounds (black boxes - vertical lines indicate discharge range and horizontal lines indicate duration range). Lower and upper red curves correspond to the $5 \%$ and $95 \%$ credible limits (middle red is median and middle black is mean), and the blue curves are models with relative likelihoods greater than 0.25 of the maximum likelihood. Outer limits of the sampling are bounded by the yellow region. 
Table 1. Mean natural (uncontrolled) peak flows at the Idaho National Laboratory Diversion Dam (data from Ostenaa and O’Connell 2005).

\begin{tabular}{cccc}
\hline Flood Type & Annual Excedance Probability & $\begin{array}{c}\text { Peak Flows } \\
\text { (cfs) }\end{array}$ & $\begin{array}{c}\text { Peak Flows } \\
\text { (cms) }\end{array}$ \\
\hline 100-year & $0.01(1 \%)$ & 3,072 & 87 \\
500-year & $0.002(0.2 \%)$ & 3,885 & 110 \\
1,000-year & $0.001(0.1 \%)$ & 4,626 & 131 \\
5,000-year & $0.0002(0.02 \%)$ & 6,639 & 188 \\
10,000-year & $0.0001(0.01 \%)$ & 9,853 & 279 \\
20,000-year & $0.00005(0.005 \%)$ & 14,691 & 416 \\
\hline
\end{tabular}

3.1.3.1 Water Depth. Inundation maps showing water depth near the two candidate sites are given in Figures 8 through 11 for the 100, 500,1,000, and 10,000-year floods. As shown in these maps, Site 5 and Site 34 are outside of the inundation area through the 1,000-year flood plain, which is the period of compliance defined by DOE Order 435.1. The rectangles shown in these maps are larger (45 acres) than the 5 -acre area that will be occupied by the proposed RH-LLW facility. Within the 45 -acre areas being considered, some of the land is within the extent of the 10,000-year flood, but water depths are predicted to be less than $0.5 \mathrm{~m}$ (more likely a few centimeters). It is also apparent that a 5-acre area not within the extent of the 10,000-year flood could be located within both 45-acre areas being considered.

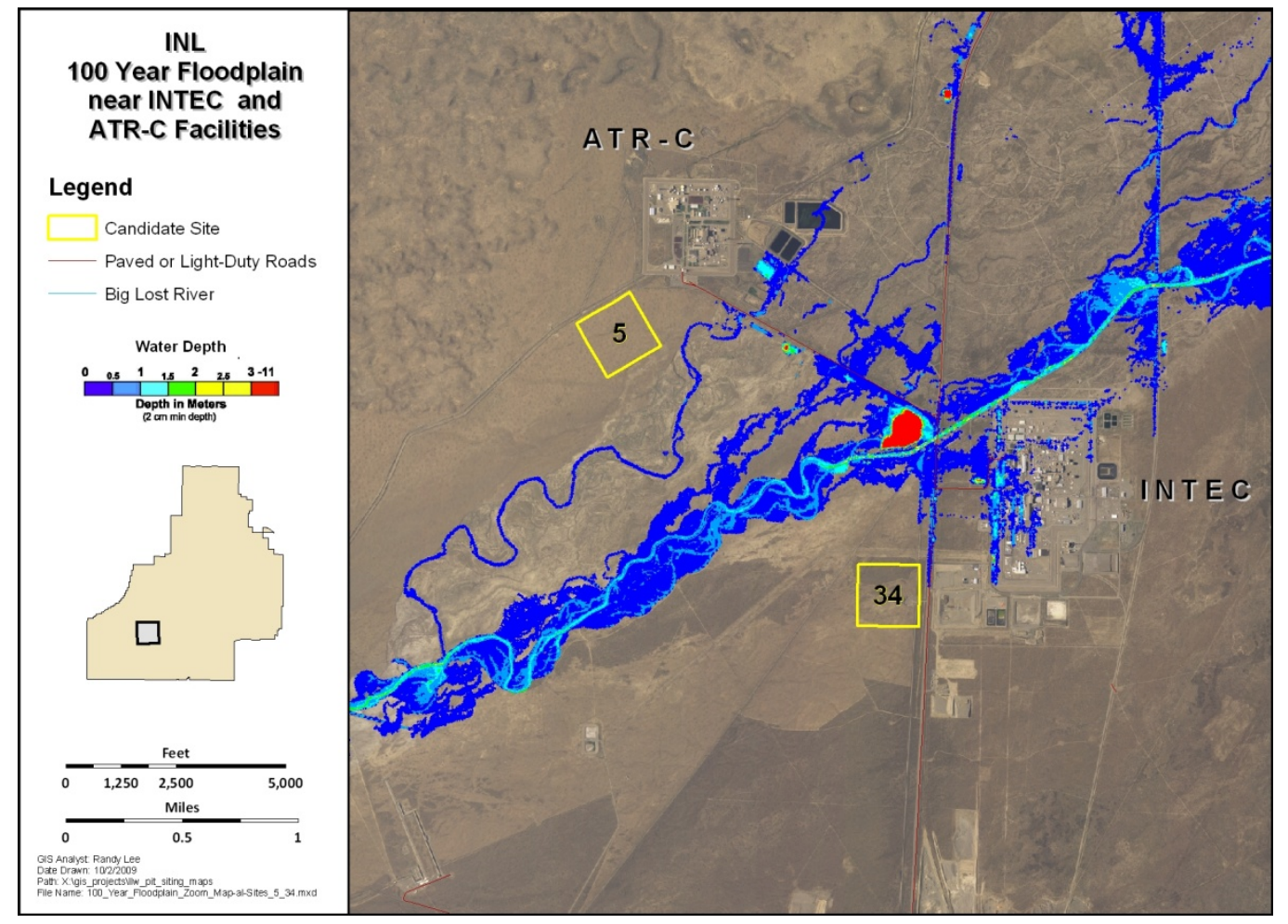

Figure 8. Water depth for the 100-year flood (87 cms peak flow at the INL Diversion Dam, 1\% annual exceedance probability). Figure adapted from Ostenaa and O’Connell (2005). 


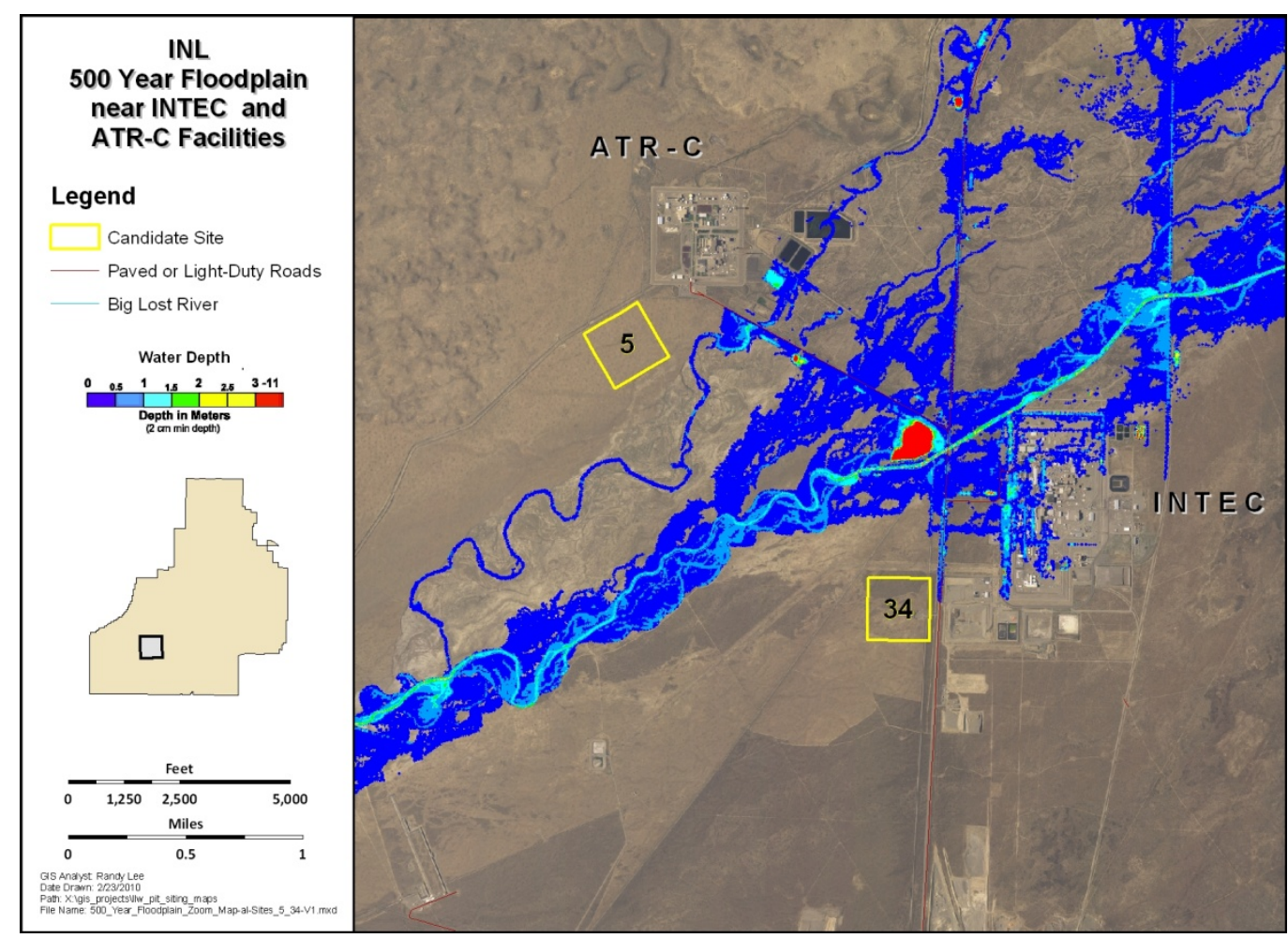

Figure 9. Water depth for the 500-year flood (110 cms peak flow at the INL Diversion Dam, 0.2\% annual exceedance probability). Figure adapted from Ostenaa and O’Connell (2005).

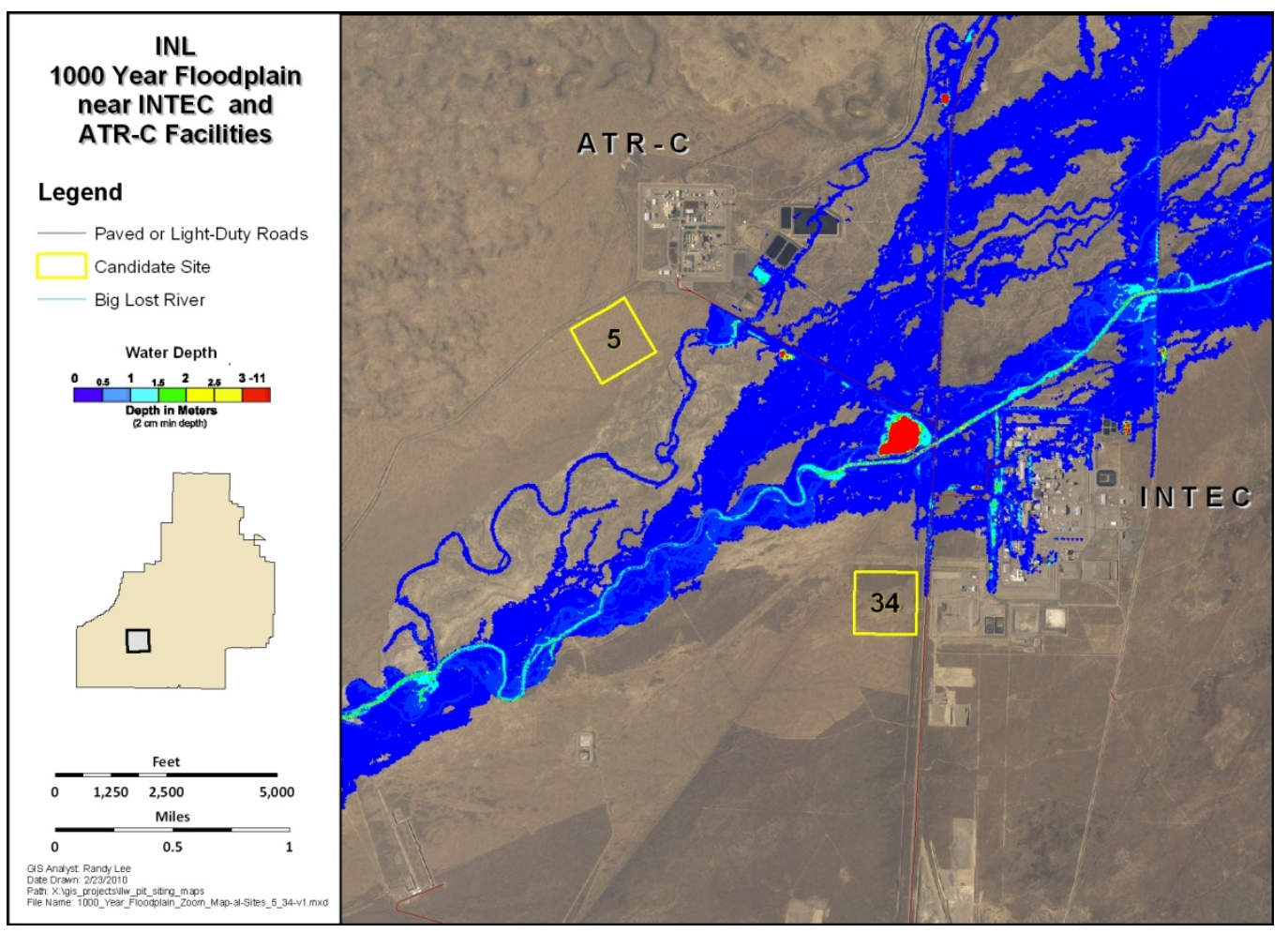

Figure 10. Water depth for the 1,000-year flood (131 cms peak flow at the INL Diversion Dam, 0.1\% annual exceedance probability). Figure adapted from Ostenaa and O’Connell (2005). 


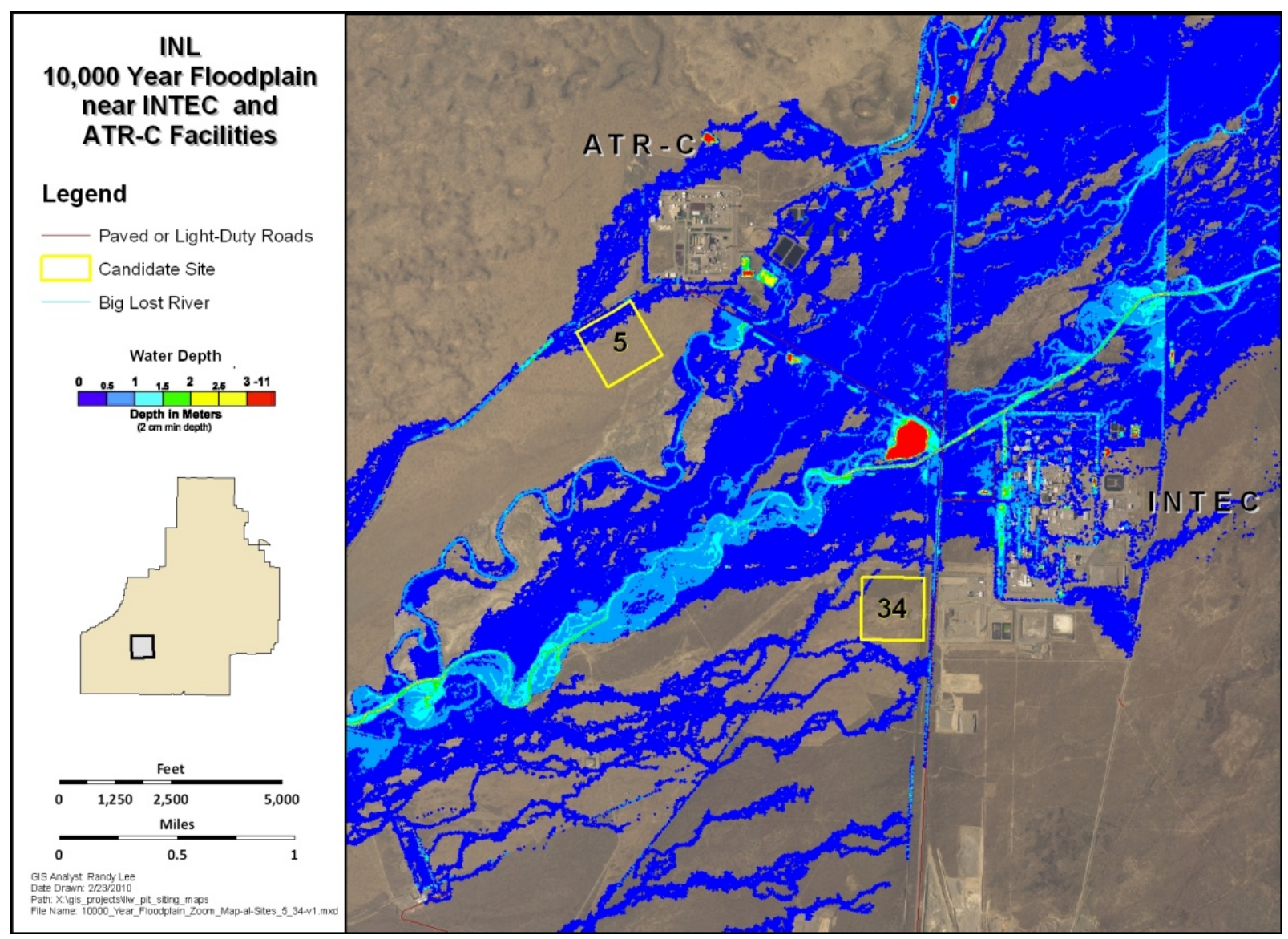

Figure 11. Water depth for the 10,000-year flood (279 cms peak flow at the INL Diversion Dam, 0.01\% annual exceedance probability). Figure adapted from Ostenaa and O’Connell (2005).

3.1.3.2 Erosion Potential. Erosion occurs when the hydraulic forces in the flow exceed the resisting forces of the channel boundary. The amount of erosion is a function of the relative magnitude of these forces and the time over which they are applied. Relative erosion potential is shown as a function of bed shear stress in Figure 12. Shear stresses corresponding to significant channel erosion affecting the course gravel mixtures near the Big Lost River are on the order of $100 \mathrm{~N} / \mathrm{m}^{2}$. Small-scale erosion of surficial material could occur in the $1-10 \mathrm{~N} / \mathrm{m}^{2}$ range in the absence of vegetative cover. However, the presence of natural vegetation would suggest that in the $1-10 \mathrm{~N} / \mathrm{m}^{2}$ range, erosion loss would be minimal.

Streambed stability has been characterized in terms of shear stress and stream power for each of the time periods given in Table 1. As shown in Figure 13, the estimated bed shear stresses for the highest flow rates corresponding to the 20,000-year flood (416 cms at the INL Diversion Dam) in the vicinity of both proposed RH-LLW locations are less than $5 \mathrm{~N} / \mathrm{m}^{2}$. It is unlikely that these rates will result in significant erosion in the presence of natural vegetative cover. 


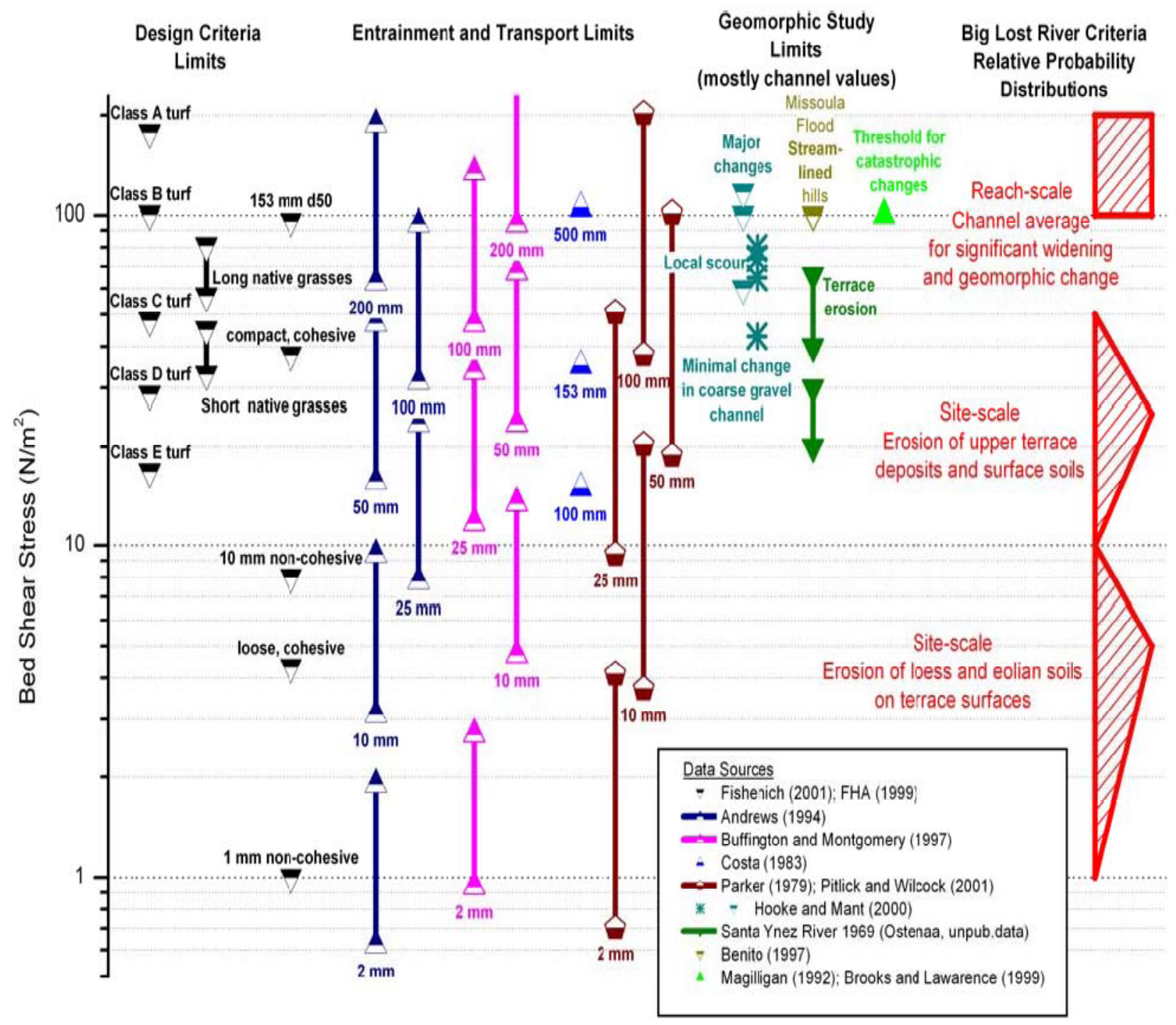

Figure 12. Summary of bed shear stress limits. Triangular symbols are oriented to indicate minimum values for entrainment or transport (pointing up, blue symbols) or maximum values (pointing down, black symbols) that are either design criteria limits or values derived from observations of erosion or transport. Values representative of Big Lost River stream stability are shown on the right. Figure from Ostenaa and O’Connell (2005). 


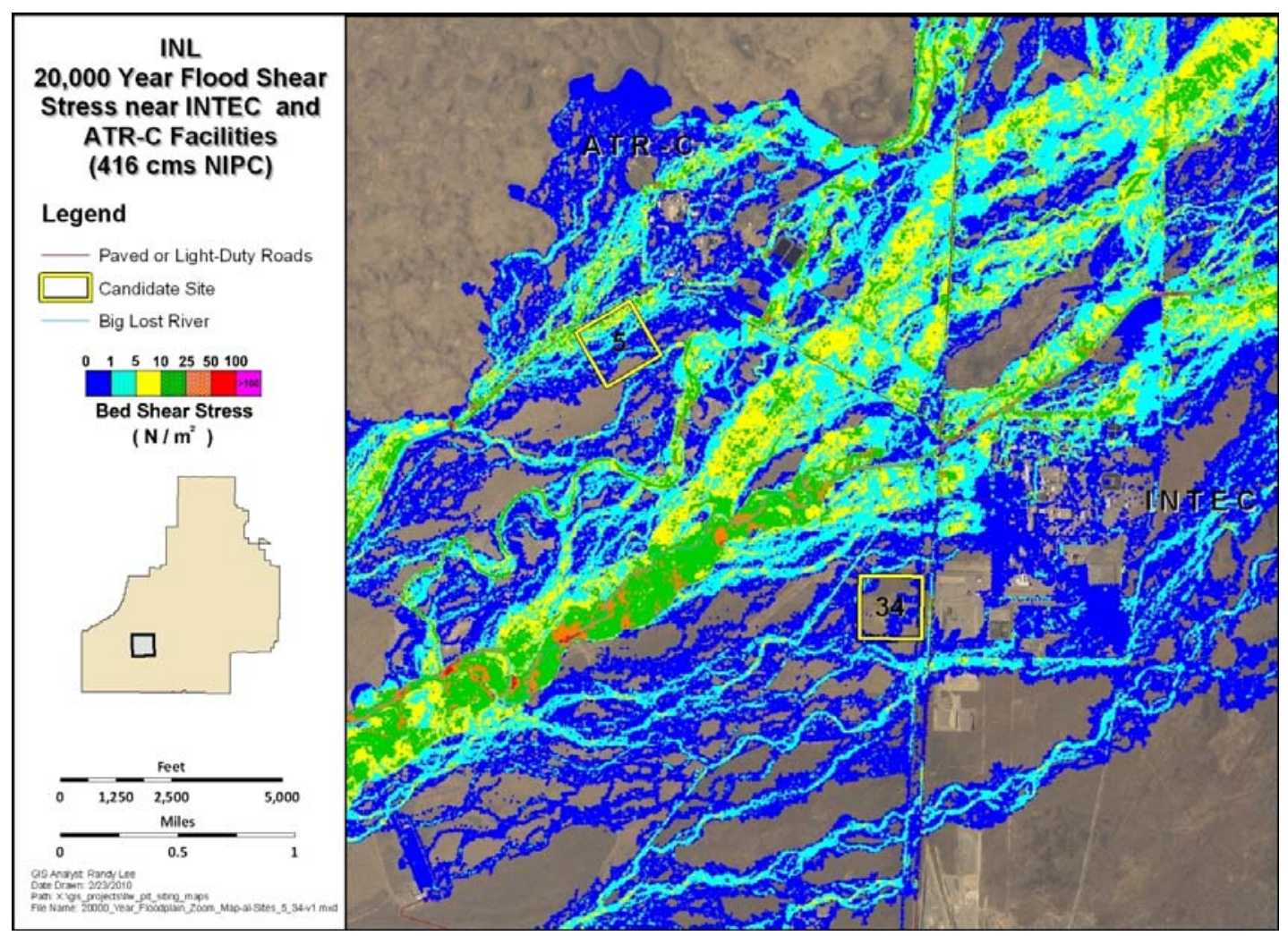

Figure 13. Bed shear stress near the Idaho Nuclear Technology and Engineering Center and the Advanced Test Reactor Complex facilities for the 20,000-year flood (416 cms flow at the INL Diversion Dam). Figure adapted from Ostenaa and O’Connell 2005.

\subsection{Extreme Local Storm Flooding Events}

In this section, the potential for onsite flooding due to extreme precipitation near the RH-LLW facilities (local precipitation) events is evaluated. Average annual precipitation is about $20 \mathrm{~cm} /$ year across much of INL. This precipitation occurs mostly in the winter months and is largely derived from moisture from the northern Pacific Ocean (Kjelstrom 1991). Although there is the potential for local flooding due to snowmelt, snowmelt typically occurs over weeks, and during the operational period, controls will be in place to route this water away from the facility. As an average value, $20 \mathrm{~cm} /$ year is insufficient to cause sufficient flooding. However, a massive local precipitation event could conceivably create floodwaters that would impact the permanent cover barrier (see Figure 3). This scenario differs from the previous analysis because the precipitation event would cause runoff of the facility cover barrier and could cause runon from the surrounding area.

To evaluate local storm induced flooding, the PMP event is used. PMP is defined as "theoretically, the greatest depth of precipitation for a given duration that is physically possible over a given size storm area at a particular geographical location at a certain time of the year" (ANS 2.8 1992). Hansen et al. (1994) have determined the 1-hour, 1- $\mathrm{mi}^{2}$ local storm PMP at INL to be $22.9 \mathrm{~cm}$ (9 in.) of rain (Figure 14). This is approximately equal to the total annual average rainfall at INL $(21.8 \mathrm{~cm}$ or 8.6 in. per year) based on the 44-year period of record at the Central Facilities Area. For comparison to the 9-in. per hour local storm PMP, a statistical analysis of meteorological data from the Central Facilities Area for the period of 1950 through 1995 provides estimates of $4.3 \mathrm{~cm}$ (1.7 in.) of precipitation for a 25-year (3.9\% AEP), 24-hour storm event and $5.6 \mathrm{~cm}$ (2.2 in.) of precipitation for a 100-year (1\% AEP), 24-hour storm event (Sagendorf 1996). Therefore, the 9 in., 24-hour local PMP is much less likely than 1\% AEP. 


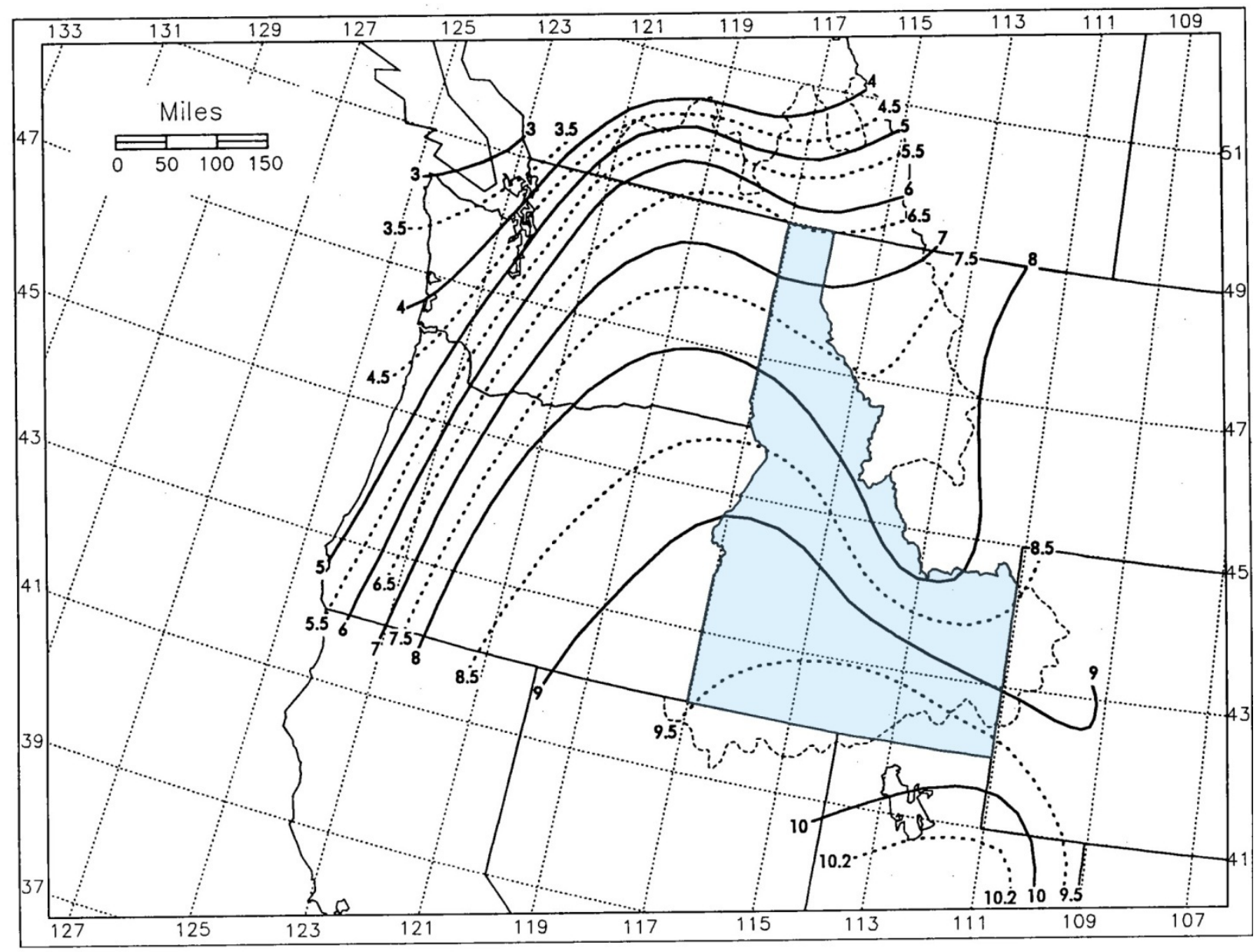

Figure 14. One hour, $1-\mathrm{mi}^{2}$ local storm probable maximum precipitation in inches for elevations to 6,000 ft. Figure from Hydrometeorological Report No. 57 (Hansen et al. 1994).

To evaluate the impacts of the local-storm, 9-in. per hour PMP, the rate of runoff from a 1-acre cap was computed. Considering a 1-acre $\left(4,047-\mathrm{m}^{2}\right)$ cap, $9 \mathrm{in}$. of rain is equivalent to $925 \mathrm{~m}^{3}$ of water. Over a period of 1 hour (3,600 seconds), this results in a flow rate of $0.25 \mathrm{cms}$ ( $8.8 \mathrm{cfs})$. Cover designs for the Radioactive Waste Management Complex (Holdren et al. 2007) and ICDF (DOE-ID 2010) both incorporate structural features sufficient to withstand this runoff rate. Flood waters at the base of these engineered covers would have to rise over $10 \mathrm{ft}$ above the existing ground surface to overtop the rock armoring (see Figure 3) emplaced on the cover side slopes. The existing ground surface surrounding both proposed sites has little relief (less than $2 \%$ ). Consequently, ground-surface level floodwaters would be relatively slow moving as compared to runoff from the approximate 7\% sloping cover surface.

\subsection{Probable Maximum Flood with Mackay Dam Failure}

This section presents an evaluation of flood waters that would result from precipitation upstream of the Mackay Dam, potentially overtopping Mackay Dam and leading to its ultimate failure. An (1) evaluation of the offsite PMP event that could occur in the drainage basin of Mackay Dam, the (2) associated probability of these events occurring, and (3) the resulting PMF that would occur if Mackay Dam failed are reviewed. As evaluated in this section, the AEP is computed from the combined probabilities and likelihoods of multiple events occurring simultaneously. 
Potential precipitation events occurring upgradient of Mackay Dam present a larger possible flood hazard than those originating from long-term historical natural flooding of the Big Lost River or from onsite generated precipitation. Precipitation scenarios possible in the drainage basin of Mackay reservoir include general-type storms, extreme thunderstorms, rainfall on snowpack, and a two-storm PMP event. All of these precipitation events, under the right set of conditions, could generate enough flow to exceed the outlet capacity of Mackay reservoir. Exceeding the outlet capacity would allow Mackay reservoir to exceed its capacity, potentially leading to failure of the dam. Combined reservoir and precipitation water would flow down the Big Lost River, eventually reaching the INL Diversion Dam. The INL Diversion Dam, constructed to divert water into INL spreading areas, would reach its capacity for diversion and the remaining water would be allowed to flow onto INL.

These combined events are possible because of the size of Mackay reservoir, higher precipitation in the drainage basin, and the use of the reservoir for irrigation, which leads to higher water volumes in the reservoir during the peak snowmelt and rain seasons. The main stem of the Big Lost River is formed by the confluence of its east fork and north fork about 22 miles northwest of Mackay Dam. The drainage basin above the dam spans roughly $788 \mathrm{mi}^{2}$. For reference, INL spans $890 \mathrm{mi}^{2}$, very little of which is covered by the Big Lost River channel. The reservoir impounds 44,500 acre-feet. Average annual precipitation in the Big Lost River basin is about $125 \mathrm{~cm} /$ year in the mountainous upper basin areas, six times higher than occurs in the Snake River Plain $(20 \mathrm{~cm} /$ year). This precipitation occurs mostly in the winter months and is largely derived from moisture from the northern Pacific Ocean (Kjelstrom 1991). Annual stream flows are dominated by the spring and early summer snowmelt and runoff from the mountains in the upper drainage basin. Snowmelt usually begins in late May or early June of each year, with significant flows extending into July. During May and early June, the ground is relatively saturated, and in preparation for the irrigation season, the reservoir is approaching full capacity, as is the river system.

Evaluation of potential onsite flooding effects of these combined precipitation and dam failure events required generation of precipitation patterns, development of flood hydrographs, and routing the hydrographs through Mackay reservoir and downstream through the Big Lost River to the INL facilities. These combined analyses were presented by Koslow and Van Haaften (1986), with the precipitation patterns and flood hydrographs developed by Schreiber (in Appendix B of Koslow and Van Haaften, 1986).

\subsubsection{Probable Maximum Precipitation and Mackay Dam Inflow Hydrographs}

To evaluate the PMF, Schreiber (Appendix B, Koslow and Van Haaften 1986) first determined appropriate PMPs for the Big Lost River drainage basin above Mackay reservoir. His evaluation then determined hydrographs for flows into Mackay reservoir. PMPs and hydrographs generated corresponded to a general-type storm, thunderstorm, and PMP on snowpack. Additionally, as suggested by the Nuclear Regulatory Commission criteria (ANS-2.8 1977), sequential rainfall events were combined in determining the general storm PMP.

Analysis of general storm conditions above Mackay reservoir predicted a 6-hour PMP of $5.4 \mathrm{~cm}$ (2.13 in.). This is roughly equal to the 1994 Hydrometeorological Report No. 57 (Hansen et al. 1994) 24-hour, $10-\mathrm{mi}^{2}$, general storm PMP shown in Figure 15 of 9 in. (1.5 in. in 6 hours). This resulted in an adjusted cumulated total rainfall of $13 \mathrm{~cm}$ (5.13 in.) over 48 hours. To determine the net general storm PMP, in accordance with the ANS-2.8 (1977) guidance, an antecedent rainfall equal to $40 \%$ of the general storm PMP was assumed to precede the single storm PMP by 72 hours, resulting in a total rainfall of $18.2 \mathrm{~cm}$ (7.18 in.). This is roughly three-quarters of the 1994 Hydrometeorological Report No. 57 value of 9 in. in 24 hours (see Figure 15), introducing some uncertainty into the previously estimated PMP rates.

Corresponding precipitation patterns were then used in the Hydraulic Engineering Flood Hydrograph Package to determine corresponding inflow to Mackay Dam. In these calculations, the base flow in the Big Lost River at the beginning of the antecedent storm was taken to be equal to a mean monthly flow of 
$30.6 \mathrm{cms}$ (1,082 cfs) during the month of June, a value slightly overestimated based on U.S. Geological Survey gage station \#13127000 data of $974 \mathrm{cms}$ (3440 cfs). The resultant peak flow into Mackay Dam for the general storm PMF was 2,324 cms (82,100 cfs) occurring 154 hours after the beginning of the storm.

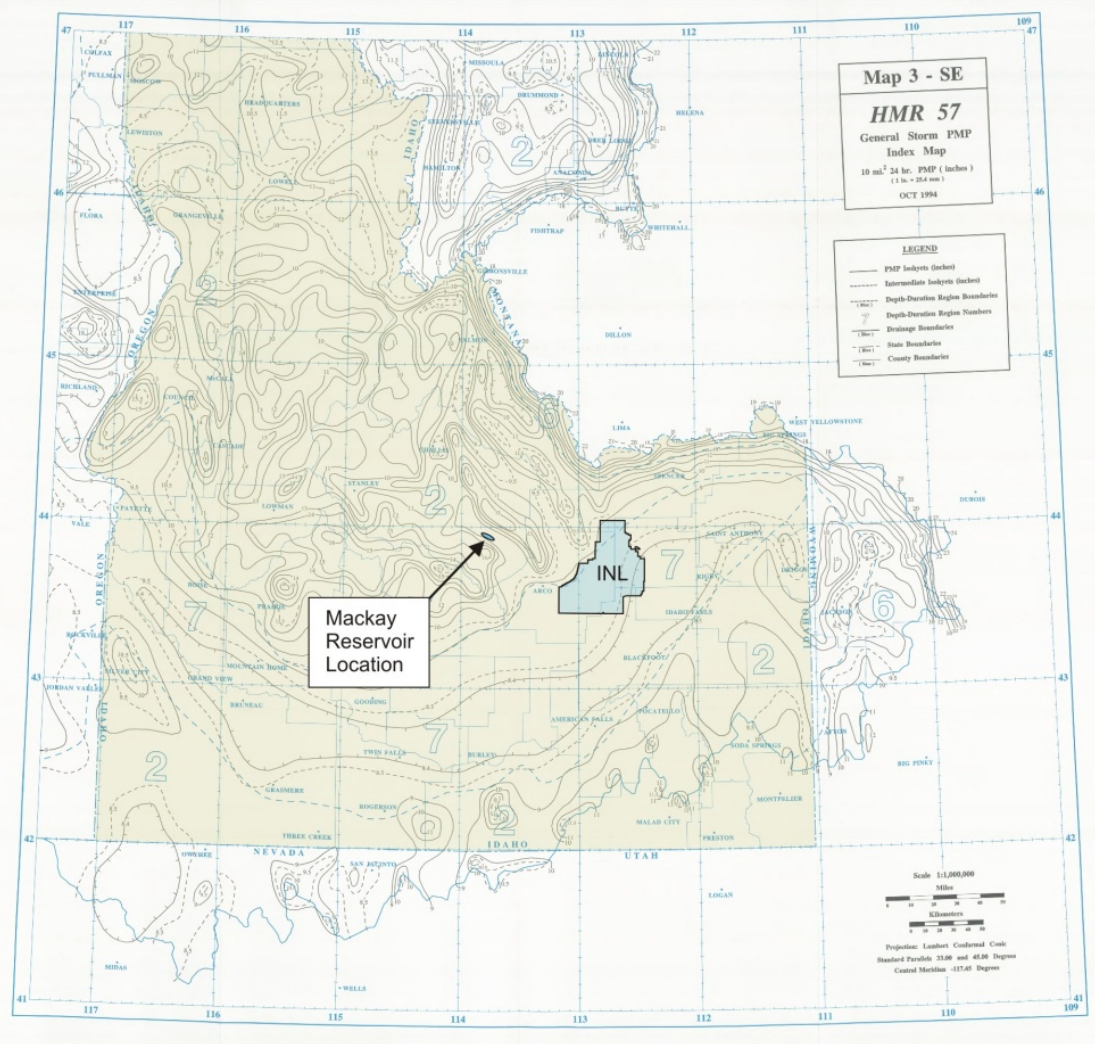

Figure 15. 24-hour, 10- $\mathrm{mi}^{2}$, general storm probable maximum precipitation in inches. Figure is from Hydrometeorological Report No. 57 (Hansen et al. 1994), and the shading and annotations were added.

Total rainfall for the thunderstorm PMP was determined to be $9.1 \mathrm{~cm}$ (3.60 in.), which was assumed to occur over a period of 1 hour. The thunderstorm was assumed to occur in August, when flows in the Big Lost River downstream of Mackay Dam are about $11 \mathrm{cms}$ (389 cfs). The peak inflow for the thunderstorm PMF was $198.5 \mathrm{cms}$ (7,010 cfs) occurring 5.5 hours after the beginning of the storm, more than an order of magnitude less than the general storm PMF.

The PMF resulting from rainfall on snowpack was evaluated for a 48-hour general storm PMP on a 100-year snowpack, with the rainfall occurring in June. Big Lost River outflow was assumed to be $30.6 \mathrm{cms}$ (1,082 cfs), which is the average for June. The entire $788 \mathrm{mi}^{2}$ drainage area was assumed to be affected. Peak flow into Mackay reservoir was estimated to be $3942 \mathrm{cms}(139,200 \mathrm{cfs})$, occurring 35 hours after the beginning of the storm, with base flow returning to $113 \mathrm{cms}$ (4,000 cfs) within 24 hours of the peak. This scenario was determined to be overly conservative due to the uncertainty involved in modeling snowpack in large basins. The general storm PMF was determined to represent a more reasonable upper-limit flooding scenario for the PMF evaluation.

The PMF resulting from the general storm PMP exceeded the outflow capacity $186.6 \mathrm{cms}(6,588 \mathrm{cfs})$ of the dam, followed by dam overtopping and complete dam failure. Assumptions and probabilities of this event occurring are discussed in the next section, followed by a discussion of approximate downstream inundation. 


\subsubsection{Probability of Combined Storm Occurrence}

Koslow and Van Haaften (1986) conducted their analysis in accordance with the 1977 ANS 2.8 guidance, which did not provide an assessment of the general storm PMF probability. Subsequently, in 1977, ANS 2.8 revised their documentation, providing the methodology for determining the probability of the PMF occurring. This guidance is reviewed below in the context of this evaluation.

In assessing the probability of combined events (two storms) occurring, the distinction between dependent and independent events is not sharp. Time sequential meteorological events, for example, are only partially and not invariably dependent and their magnitudes also are only partially and not invariably dependent. However, the following estimate (adapted from ANS 1992) shows that the probability of the two-storm sequence occurring during the month of June leading to the Mackay Dam failure and a subsequent PMF is extremely small and is on the order of $2.5 \times 10^{-9}$. This is conservative because it assumes unit probability that (1) the dam is full, (2) the dam breaches as it is overtopped, and (3) that no sedimentation occurs in the reservoir throughout its lifetime.

- According to ANS 2.8 guidance (ANS 2.8 1992), the probability of the first storm event was chosen such that it had virtually no chance of being exceeded. A probability of $1 \times 10^{-6}$ or $1 \times 10^{-7}$ is sensibly zero, but a more conservative value of $1 \times 10^{-4}$ is typically used.

- By virtue of the method used to select the PMP, it has an annual probability of occurring somewhere in a homogeneous basin. The likelihood of its occurrence most effectively located and time-distributed on a specific watershed of the Mackay Dam drainage is much less. A $1 \times 10^{-1}$ annual probability is used for example, yielding a combined annual probability of $1 \times 10^{-5}$.

- Two heavy rains separated by a short dry interval may occur, but not invariably. Here, a 50-50 chance is presumed, probability $=0.5$, now yielding a combined probability of $5 \times 10^{-6}$.

- The PMP results from a postulated completely saturated atmosphere. A closely time-spaced prior or following rain is unlikely to have such a plentiful moisture source. For practical purposes, the standard specifies $40 \%$ of the PMP, or a 500 -year rain, whichever is less. Using a 500 -year storm, (probability $=1 / 500$ ), the combined probability is $1 \times 10^{-8}$.

- Median soil moisture conditions and an average monthly base flow would precede these heavy rains. Each has a 0.5 probability, resulting in a combined annual probability of $2.5 \times 10^{-9}$.

- The probabilities associated with the storm events leading up to the PMF yields a final combined probability of $2.5 \times 10^{-9}$, corresponding to a return period of $4 \times 10^{8}$ years.

- Accounting for wind effects would further reduce this probability.

\subsubsection{Predicted Flow and Duration at the Idaho National Laboratory Diversion Dam and Downstream}

Downgradient flows were predicted using a one-dimensional model for the resultant dam breach in combination with the PMF occurring in the drainage basin of Mackay reservoir (Koslow and Van Haaften 1986). Resultant peak Big Lost River discharge (flow) rates are shown in Figure 16 just south of Mackay Dam, at the INL Diversion Dam, and at INL TAN.

- Peak in-channel discharge predicted at the INL Diversion Dam was 2,035 cms (71,850 cfs). Peak rates near the ATR Complex and INTEC were similar at 1,897 cms (67,000 cfs), and 1,902 cms (67,170 cfs), respectively. By the time the floodwaters were predicted to reach TAN, overland flow combined with in-channel infiltration had reduced the peak rate to $986 \mathrm{cms}$ (34,810 cfs) (see Figure 16).

- Elapsed time for the flows south of Mackay reservoir to return to pre-flood conditions was less than 48 hours. Flood waters were predicted to reach the INL Diversion Dam in 10 hours, with rates 
reduced to $651 \mathrm{cms}(23,000 \mathrm{cfs})$ within 30 hours after dam breach and 20 hours after reaching the INL diversion.

- Peak water velocities at the ATR Complex and INTEC were similar at $84 \mathrm{~cm} / \mathrm{sec}(2.75 \mathrm{ft} / \mathrm{sec})$.

- Water depth in the Big Lost River channel was predicted to be 150 to $180 \mathrm{~cm}$ (5 to $6 \mathrm{ft}$ ), and overland depth near the ATR Complex and INTEC was predicted to be on the order of 61 to $123 \mathrm{~cm}$ (2 to $4 \mathrm{ft}$ ).

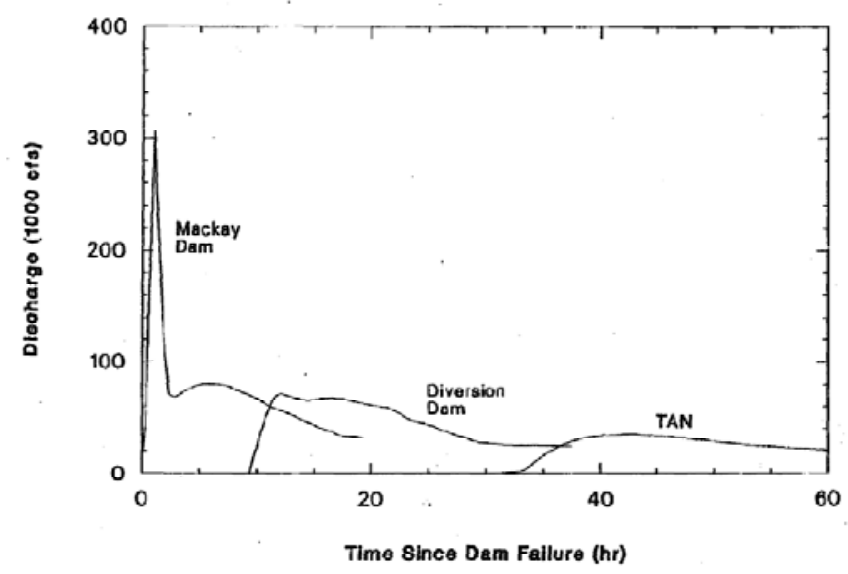

Figure 16. Discharge hydrographs for the probable maximum flood-induced dam failure. Rates are shown for just south of Mackay Dam, at the INL Diversion Dam, and at TAN (Koslow and Van Haaften 1986).

\subsection{Seismic Failure of Mackay Dam During a 25-Year Flood}

This section reviews expected flood waters at INL that would be released during a combined flooding and seismic failure of Mackay Dam. To make this evaluation, Koslow and Van Haaften (1986) assumed the dam would fail during the 500-year general storm PMP occurring in the Mackay reservoir drainage. The postulated seismic failure of Mackay Dam was assumed to occur during an inflow to the reservoir equal to the 25-year flood of $114 \mathrm{cms}(4,030 \mathrm{cfs})$. The failure scenario assumed significant disruption of the dam's structure extending from the top of the dam to the bottom of the structure in trapezoidal pattern. Complete failure of the dam was assumed to occur over a 1-hour period.

\subsubsection{Probability of Combined Storm and Seismic Event Occurrence}

The probability of a concurrent seismic event and 25-year flood occurring is much less than the probability of either event occurring. Although not evaluated by Koslow and Van Haaften (1986), a similar analysis is provided for the safe shutdown earthquake scenario in ANS 2.8 (1992). A safe shutdown earthquake is the most severe standard associated with nuclear power plant operation. It assumes an earthquake with a return period of 10,000 years concurrent with a 25-year flood with pre-flood reservoir elevations at the upper level of the dam operating rule. The following analysis shows that the probability of the concurrent seismic event and 25-year storm event leading to the Mackay Dam failure is extremely small and is on the order of $2.2 \times 10^{-9}$ :

- According to ANS 2.8 guidance, a Category 1 facility must have a safety probability of $1 \times 10^{-6}$ or $1 \times 10^{-7}$. Probability of $1 \times 10^{-6}$ or $1 \times 10^{-7}$ is sensibly zero, but a more conservative value of $1 \times 10^{-4}$ is typically used. The proposed RH-LLW facility is a lower Category 2 facility, but we will adopt the $1 \times 10^{-4}$ design criteria. This is roughly equal to the exceedance probability of the 1983 magnitude 6.9 Borah Peak earthquake $\left(1.7 \times 10^{-4}\right)$, based on a return period estimated at 6,000 years (Figure 4-9 of INEL 1996). 
- We assume the epicenter of safe shutdown earthquake for its tectonic region to be imposed at a location that ensures maximum dam failure surge. The likelihood of this specific centering is given a 1 in 10 chance. Total safe shutdown earthquake influence has an annual probability of $1 \times 10^{-5}$.

- A prescribed 25-year flood has probability 0.04 and has no better than a 2-day out of 365-day chance (probability $=0.0055$ ) of peaking in the reservoir coincident with the safe shutdown earthquake. The combined annual probability is then $2.2 \times 10^{-9}$. This corresponds to a return period of $4.5 \times 10^{8}$ years, slightly greater than the PMF return period.

The previous evaluation is conservative because it assumes dam failure with unit probability. However, this dam has withstood the 1983 Borah Peak magnitude 6.9 earthquake in the near vicinity (11 miles from epicenter), with no adverse impacts to the dam abutments or underfloor. It also is conservative because it assumes unit probability that (1) the dam is full, (2) the dam breaches as it is overtopped, and (3) that no sedimentation occurs in the reservoir throughout its lifetime.

\subsubsection{Predicted Flow and Duration at the Idaho National Laboratory Diversion Dam and Downstream}

Flow discharges predicted by the one-dimensional DAMBRK model were included in tabular form for the region just south of Mackay Dam, at the INL Diversion Dam, and close to TAN by Koslow and Van Haaften (1986). We can interpret these velocities to be in-channel because of the narrow transverse corridor at these locations. Predicted results relevant to the proposed RH-LLW facility locations include the following:

- Peak flows at the INL Diversion Dam of 1,490 cms (45,410 cfs)

- Peak stream velocities near the ATR Complex and INTEC of about $75 \mathrm{cms}(2.5 \mathrm{ft} / \mathrm{sec})$

- Peak water depth in the channel near the proposed RH-LLW sites of about 152 (5 ft)

- Peak overland water depth near the proposed RH-LLW sites of about $122 \mathrm{~cm}$ (4 ft)

- Elapsed time for the flood water to reach the INL Diversion Dam for the seismically induced flood scenario was approximately 12 hours (Figure 17). Flows 20 hours after the peak arrival at the INL Diversion Dam had reduced to $283 \mathrm{cms}$ (10,000 cfs).

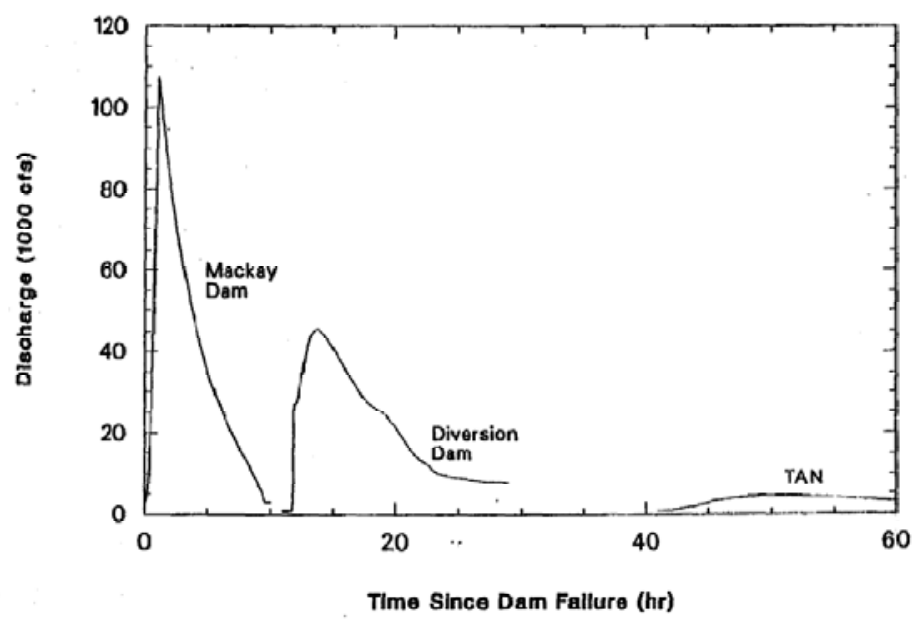

Figure 17. Discharge hydrographs for the seismically induced dam failure. Rates are shown for just south of Mackay Dam, at the INL Diversion Dam, and at TAN (Koslow and Van Haaften 1986). 
The Koslow and Van Haaften (1986) analysis did not incorporate observed increases in discharge that resulted during the Borah Peak earthquake of 1983. The Borah Peak earthquake occurred on October 28, 1983, and is the largest recorded earthquake in Idaho, registering 7.3 on the Richter scale. Immediate effects of this earthquake included a significant change in groundwater and surface water conditions in the basin upgradient of Arco; however, local flow conditions downstream of Arco did not seem to be as affected by the earthquake (Hortness and Rousseau 2003). Hortness and Rousseau (2003) estimate that upgradient of Arco stream flows were increased by as much as five times, while at the INL Diversion Dam, the recorded stream flow only increased by about $10 \%$. As a result, the additional flows that may occur during a seismic event are captured by the extreme PMF case analyzed by Koslow and Van Haaften (1986) where the seismic event results in complete dam failure and higher overall flows.

\subsection{Hydraulic Piping Failure of Mackay Dam During 100 and 500-Year Floods}

This section reviews predicted flood waters at INL that would be released during a potential hydraulic piping failure of Mackay Dam. This event is evaluated for two different precipitation scenarios corresponding to 100-year and 500-year floods resulting from precipitation events. The larger return period for the precipitation events relative to the 25-year flood and seismic failure scenario would suggest that piping failure would be less likely to occur. However, piping failure is one of the most common causes of dam failure. Piping phenomena include (1) heave, (2) internal erosion, and (3) backward erosion. The principle difference between a piping failure and failure leading to the PMF discussed in Section 3.3 is the coincident inflow to the reservoir, the reservoir water surface elevation at the time of failure, and the mode of failure. For this scenario, the breach was assumed to develop over a 1-hour period, and to extend from the top of the dam to the bottom of the dam. Coincident conditions included a 100-year and 500-year flood with peak inflows of 139 and $163 \mathrm{cms}$ (4,870 and 5,760 cfs), respectively. The resultant breach for the 100-year precipitation scenario was assumed to be triangular, extending from the spillway top to the dam base while the breach was assumed to be trapezoidal for the 500 -year precipitation scenario to evaluate geometric assumptions.

\subsubsection{Probability of Combined Storm and Hydraulic Piping Failure Occurrence}

The probability of a concurrent piping failure and flood of a specific return period occurring is less than the probability of either event occurring. Although not evaluated in the Koslow and Van Haaften (1986) report, following the logic provided in ANS 2.8 (1992) for combined events, an approximate probability can be assigned. The analysis assumes a return period for piping failure of 100 years, equal to the current life of the dam. This is conservative because, as previously mentioned, Mackay Dam withstood the magnitude 6.9 Borah Peak earthquake (epicenter 11 miles away), with no adverse impacts to the dam abutments or underfloor. It also is conservative because it assumes unit probability that (1) the dam is full, (2) the dam breaches as it is overtopped, and (3) that no sedimentation occurs in the reservoir throughout its lifetime.

Two cases of interest, corresponding to the 100-year, and 500-year concurrent storm scenarios are evaluated. In these calculations, the design life, $n$ (see Section 3.1.2), is assumed to be 100 years when evaluating the probability of piping failure in the average return period.

- A probability of $1 \times 10^{-2}$ is conservatively assumed for piping failure.

- We assume the piping failure goes unrecognized and is imposed at a location that ensures the maximum dam failure surge. The likelihood of this specific centering is given a 1 in 10 chance. Total piping failure influence then has an annual probability of $1 \times 10^{-3}$.

- A prescribed 100-year flood has probability 0.01 and has probability of 0.63 of peaking in the reservoir coincident with a 100-year piping failure (ANS 2.8 1992). Combined annual probability is $6.3 \times 10^{-6}$. This corresponds to a return period of $1.6 \times 10^{5}$ years. 
- A prescribed 500-year flood has probability 0.002 and has higher probability (0.18) of peaking in the reservoir coincident with the 100-year piping failure (ANS 2.8 1992). Combined annual probability for this scenario is overall much lower than the 100 -year event, with probability equal to $3.6 \times 10^{-7}$. This corresponds to a return period of $2.8 \times 10^{6}$ years.

\subsubsection{Predicted Flows and Duration at the Idaho National Laboratory Diversion Dam}

The same one-dimensional flood routing model of the Big Lost River channel was applied to analyze this flood scenario by Koslow and Van Haaften (1986). Predicted results include the following:

- Peak in channel flows at the INL Diversion Dam of $807 \mathrm{cms}(28,500 \mathrm{cfs})$ for the piping failure coincident with the 100-year flood.

- Peak flows at the INL Diversion Dam of 1,300 cms (45,910 cfs) for the piping failure coincident with the 500-year flood.

- Peak stream velocities near the ATR Complex and INTEC of 43 to $82 \mathrm{cms}$ (1.4 to $2.7 \mathrm{ft} / \mathrm{sec}$ ) for both the 100-year and 500-year flood scenarios.

- Peak water depth in the channel of 122 to $152 \mathrm{~cm}$ (4 to $5 \mathrm{ft}$ ); increasing the coincident rates by $60 \%$ for the 500-year flood did not significantly change either water velocity or water depth near the ATR Complex or near INTEC.

- Elapsed time for the flood water to reach the INL Diversion Dam for the 100-year flood scenario was approximately 13 hours and 12 hours for the 500-year flood.

\subsection{Annual Exceedance Probability and Flooding Summary}

Flood water discharge rates at the INL Diversion Dam for each of the scenarios discussed previously are shown in Table 2 and compared graphically in Figure 18. The flood types compared are a combination of natural (uncontrolled by Mackay Dam) historical floods determined by Ostenaa and O'Connell (2005); and natural floods or precipitation events combined with different Mackay Dam failure modes as determined by Koslow and Van Haaften (1986).The PMP with Mackay Dam failure represents the highest peak flow rate and was deemed the PMF by Koslow and Van Haaften (1986). Natural flow discharges increase with longer return periods as illustrated in Figure 7. This pattern is not apparent in the dam failure scenarios where the discharge rate is higher for the 25-year flood combined with a seismicevent-induced dam failure than for the 100-year flood combined with a hydraulic piping induced dam failure. The lower discharge rate during the 100-year flood and hydraulic piping induced dam failure breach relative to the other scenarios is primarily due to the assumption of triangular rather than trapezoidal breach configuration. The triangular breach essentially reduces the outlet cross-sectional area by a half, increasing the time required for the reservoir to empty, and decreasing the outlet flow rate. The other dam failure scenarios all assumed a trapezoidal breach extending from the dam spillway (elevation $6,067 \mathrm{ft}$ ) to the bottom at elevation $5,997 \mathrm{ft}$.

- Discharge rates, erosion potential, and onsite duration of water is highest for the PMF scenario. However, the probability of the PMF occurring is lowest $\left(2.5 \times 10^{-9}\right)$ as discussed in Section 3.3.3.

- Slower discharge, lower erosion potentials, and shorter onsite duration of water were predicted for the remaining concurrent flood-inducing dam failures. The probability of occurrence for the seismic induced flood is $2.2 \times 10^{-9}$ (Section 3.4.1). Return periods for the coincident piping-flood scenarios were estimated at $6.3 \times 10^{-6}$ and $3.6 \times 10^{-7}$ for the 100 -year and 500 -year failures, respectively (Section 3.5.1). 
- Compared to the Mackay Dam failure scenarios, discharges within a 1,000-year return period are an order of magnitude smaller as determined by the geologic record along the Big Lost River; however, the probability of exceeding the lower flows is higher. As the AEP is reduced, the estimated peak flow increases. For a 20,000-year natural flow flood, discharge rates are predicted to be within 25\% of the flooding scenarios occurring coincident with a Mackay Dam failure.

- The probability of flow rates high enough to reach the proposed facility locations within the 1,000-year performance period is approximately $9.5 \%$.

Table 2. Mean natural (uncontrolled) peak flows at INL Diversion Dam, including the assessments of the probable maximum flood and other dam failure scenarios.

\begin{tabular}{|c|c|c|c|c|}
\hline Flood Type & $\begin{array}{c}\text { Annual Exceedance } \\
\text { Probability }\end{array}$ & $\begin{array}{l}\text { Return } \\
\text { Period } \\
\text { (years) }\end{array}$ & $\begin{array}{c}\text { Peak Flow } \\
\text { (cfs) }\end{array}$ & $\begin{array}{c}\text { Peak Flow } \\
(\mathrm{cms})\end{array}$ \\
\hline $100-$ year $^{\mathrm{a}}$ & $0.01(1 \%)$ & $1.0 \times 10^{2}$ & 3,072 & 87 \\
\hline 500-year ${ }^{\mathrm{a}}$ & $0.002(0.2 \%)$ & $5.0 \times 10^{2}$ & 3,885 & 110 \\
\hline 1,000 -year ${ }^{\mathrm{a}}$ & $0.001(0.1 \%)$ & $1.0 \times 10^{3}$ & 4,626 & 131 \\
\hline 5,000--year ${ }^{\mathrm{a}}$ & $0.0002(0.02 \%)$ & $5.0 \times 10^{3}$ & 6,639 & 188 \\
\hline $10,000-$ year $^{\mathrm{a}}$ & $0.0001(0.01 \%)$ & $1.0 \times 10^{4}$ & 9,853 & 279 \\
\hline 20,000-year ${ }^{\mathrm{a}}$ & 0.00005 (0.005\%) & $2.0 \times 10^{4}$ & 14,691 & 416 \\
\hline 25-year (dam fail-seismic) ${ }^{\mathrm{b}}$ & $2.2 \times 10^{-9}$ & $4.5 \times 10^{8}$ & 45,410 & 1,286 \\
\hline 100-year (dam fail-piping) ${ }^{\mathrm{b}}$ & $6.3 \times 10^{-6}$ & $1.6 \times 10^{5}$ & 28,500 & 807 \\
\hline 500-year (dam fail-piping) ${ }^{\mathrm{b}}$ & $3.6 \times 10^{-7}$ & $2.8 \times 10^{6}$ & 45,910 & 1,300 \\
\hline PMF (PMP and dam fail-overtop) ${ }^{\mathrm{b}}$ & $2.5 \times 10^{-9}$ & $4.0 \times 10^{8}$ & 71,850 & 2,035 \\
\hline
\end{tabular}

a. Ostenaa and O’Connell (2005)

b. Koslow and Van Haaften (1986) estimated peak flows only. AEPs and return periods estimated by this study.

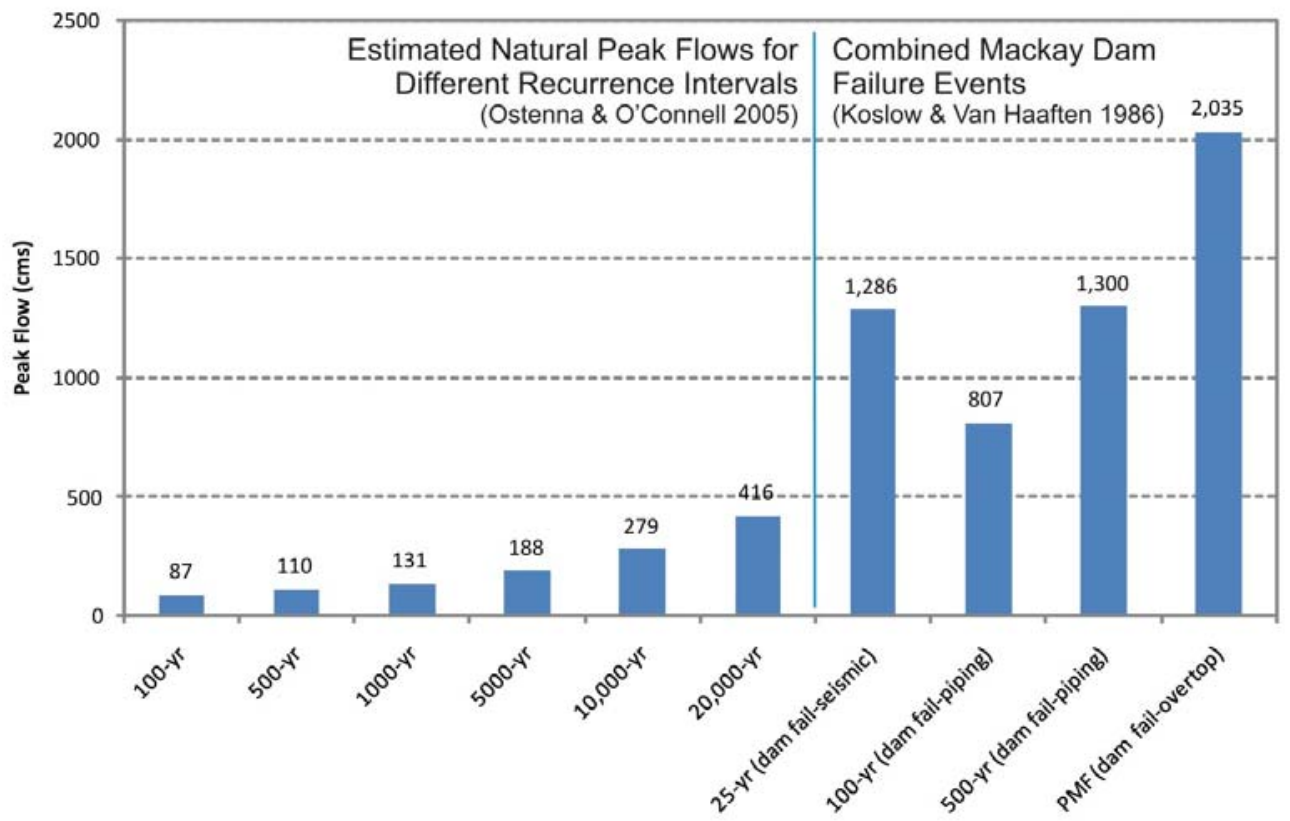

Figure 18. Comparison of estimated peak flow rates at the Idaho National Laboratory Diversion Dam for different flood scenarios. Data from Ostenaa and O'Connell (2005) and Koslow and Van Haaften (1986). 


\section{EVALUATION OF PROBABLE FLOODING CONSEQUENCES AT THE PROPOSED REMOTE-HANDLED LOW-LEVEL WASTE DISPOSAL FACILITY SITES}

The ability of the important flood sources to impact facility design and long-term facility performance are evaluated in this section. Flooding consequences are measured in terms of the potential for flood water to damage a facility or to increase contaminant transport from the facility. Simplistically, damage can be caused by erosion and increased contaminant transport can be caused by excessive infiltration or long-term infiltration. Performance measures for this damage can be evaluated in terms of onsite water:

- Depth - used as a surrogate for hydraulic driving force or infiltration and also evaluated for potential to contribute to erosion.

- Erosion potential - quantified in terms of bed shear stress. Bed shear stress has been correlated to movement of soils on terrace surfaces, erosion of upper terrace deposits, and to significant geomorphic channel change.

- Duration of onsite water - evaluated for its ability to impact total (net) infiltration of ponded water and its ability to influence erosion.

- Subsurface underflow - evaluated for its potential to mobilize contaminants. The amount of increased mobilization is, in part, a function of ponded water depth and duration and is very much influenced by the return-period for presumed flooding events.

Viewed in this context, flood consequences are largely independent of the specific source of flood water. This allows analysis of impacts by consequence as opposed to an evaluation across flood-water source. It also allows use of the numerical predications of flood water depth and bed shear stress predicted by Ostenaa and O'Connell (2005) to assess impacts for all flood water sources because their work evaluated inundation across INL for a sufficient range of discharges at the INL Diversion Dam. As complimentary information, Koslow and Van Haaften (1986) provided the information required to assess flood water duration at key INL locations. The combined information provides the basis for the consequence analyses discussed in the following subsections.

\subsection{Depth of Onsite Water}

Depth of onsite water for both proposed RH-LLW sites (Site 5 and Site 34) are similar for INL diversion discharge rates represented by the 100-year, 500-year, 1,000-year, and 10,000-year flood plain analysis as shown in Figures 8 through 11. These time periods are key from a design, operation, and performance perspective as discussed in the following bullets, although the associated flow rates do not span those predicted to occur during the Mackay Dam failure scenarios. However, as shown in the following, Ostenaa and O'Connell (2005) did provide a representative simulation that can be used in this analysis.

For design purposes, it is necessary to determine the depth of onsite water throughout the design life of the facility. As shown in Figure 10, both proposed locations are outside of the 1,000-year flood plain, which is the period of compliance defined by DOE Order 435.1. As shown in Figure 11, portions of the 45-acre areas being considered are within the extent of the 10,000-year flood, but water depths are predicted to be less than $0.5 \mathrm{~m}$ (not more than a few centimeters). Five acre areas within both candidate 45-acre areas being considered can be found that are not within the extent of the 10,000-year flood.

The associated rates for these previously discussed events coincide with the design periods, but do not include the higher rates predicted for the suite of Mackay Dam failure scenarios. However, a simulation of flood water inundation for a 1,902-cms (67,168-cfs) discharge rate at the INL Diversion Dam was provided by Ostenaa and O'Connell (2005). This is approximately equal to the PMF flow (2,035 cms) and is much greater than the flows predicted to occur under the other combined event failures of Mackay 
Dam. This simulation provides the bounding depth for all flooding scenarios expected to impact the proposed RH-LLW disposal facility. The AEP for this rate should be interpreted in the context of the scenarios discussed in Sections 3.3, 3.4, and 3.5.

The resultant water depth for the 1,902-cms discharge (Figure 19) shows that even though the overall extent of surface water is larger than predicted for the natural flow events. The predicted water depth near the candidate sites is still less than $0.5 \mathrm{~m}$ with the exception of the water depth in a borrow pit within the 45 acres being considered at Site 34.

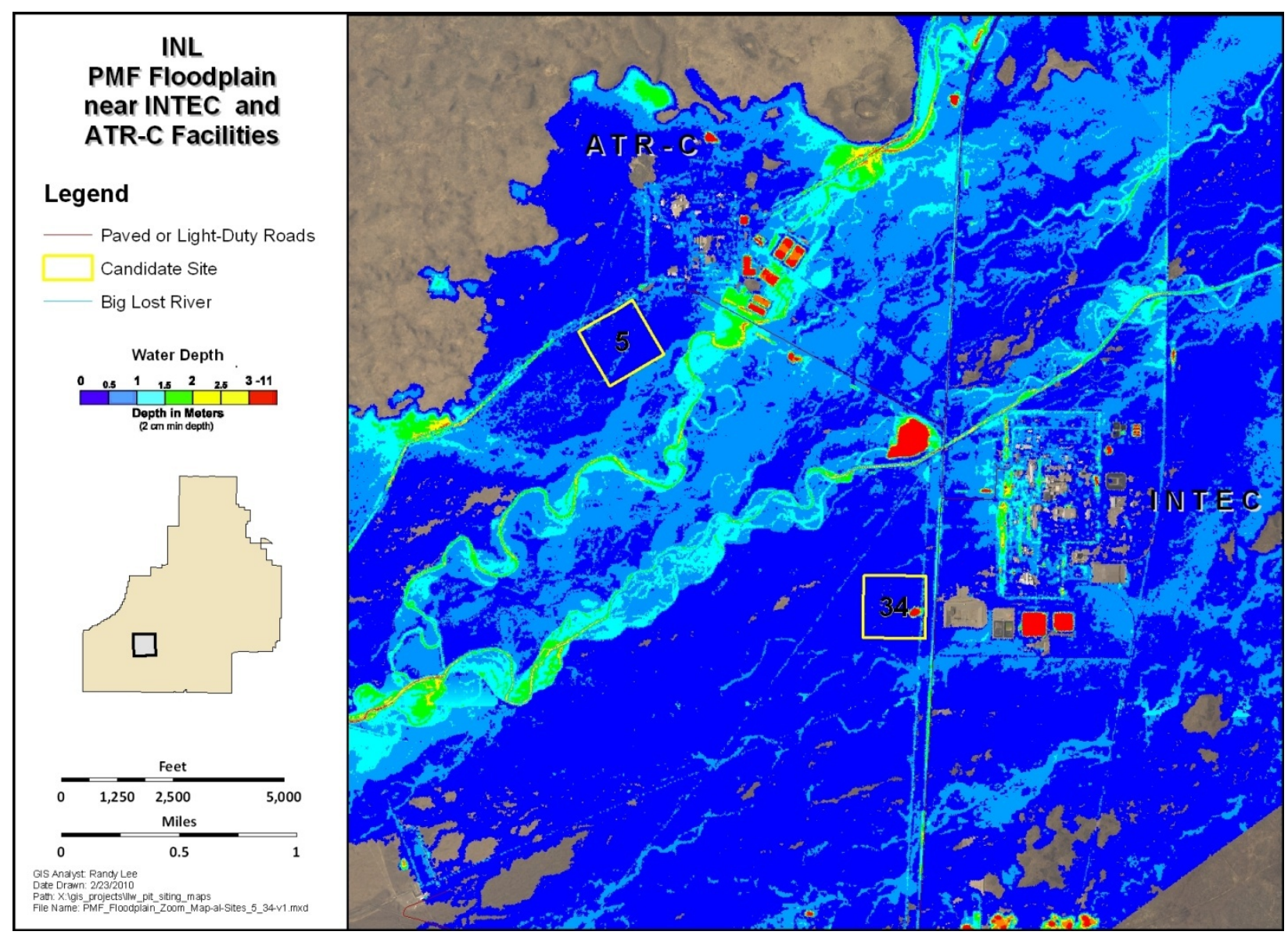

Figure 19. Water depth for the 1,902-cms flow rate at the INL Diversion Dam. This flow is approximately equal to the probable maximum flood flow of Koslow and Van Haaften (1986). Figure adapted from Ostenaa and O’Connell (2005).

From a facility design and operations perspective, the relatively shallow predicted flood water depth has different potential impacts, depending on the time period. These impacts are as follows:

- During the operational period (50 years), water depth would be highest for all of the flooding scenarios during the local extreme onsite precipitation event of 9 in. per hour. Incursion of water during extreme precipitation events will not adversely impact the concrete vaults, their steel liners, and are not expected to mobilize contaminants from them. The sand infill between the concrete vaults and gravel underlayment is designed to transport water away from the vault. Water flowing toward the facility during extreme local precipitation events within this time period can be controlled by emplacing a low berm around the facility. Berm integrity can be assured because of the relatively low expected overland velocity and shallow water depth. 
- During the compliance period (1,000 years), it is highly unlikely that water depths will exceed the depths predicted by the 1,902-cms flood model. These depths are less than $0.5 \mathrm{~m}$. Further, because of the cover design, flood waters at the base of the engineered cover would have to rise over $10 \mathrm{ft}$ above the existing ground surface to overtop the rock armoring (see Figure 3) emplaced on the cover side slopes. The existing ground surface surrounding both proposed sites has little relief (less than $2 \%$ ). Local extreme precipitation events have been accounted for in the barrier design through emplacement of the rock armoring and the gravel-soil mixed top layer. Consequently, ground-surface level floodwaters generated from barrier runoff would be relatively slow moving as compared to runoff from the approximate $7 \%$ sloping cover surface.

- During the post-compliance period, beyond 1,000 years, the worst case scenario is again presented by the PMF, assuming Mackay Dam remains in a similar configuration. Other dam failure scenarios present lower, but similar, flood peak flows. However, because the flow rates associated with these scenarios are about the same as the 1,902-cms flow modeled by Ostenaa and O'Connell (2005), the water depths would be about the same (less than $0.5 \mathrm{~m}$ ).

\subsection{Erosion Potential of Onsite Water}

Relative erosion potential was shown as a function of bed shear stress in Figure 12. Shear stresses corresponding to significant channel erosion affecting the course gravel mixtures near the Big Lost River are on the order of $100 \mathrm{~N} / \mathrm{m}^{2}$. Small-scale erosion of surficial material could occur in the $1-10 \mathrm{~N} / \mathrm{m}^{2}$ range in the absence of vegetative cover. However, the presence of natural vegetation would suggest that in the $1-10 \mathrm{~N} / \mathrm{m}^{2}$ range, erosion loss would be minimal.

Model predictions of erosion potential through the 20,000-year return period are substantiated by the geomorphic investigations of Ostenaa et al. (1999). As shown in Figure 4, the quaternary geology was investigated in soil pits located proximal to both proposed facility locations. Soil ages nearest the proposed sites are within the 10 to 50 ka range (see Table 3). Soils closer to the river are at least 1,000 years old. These ages support the extent of predicted flood water and erosion potential relationship model.

Table 3. Geomorphic soil ages near proposed Site 5 and Site 34 (see Figure 4).

\begin{tabular}{|c|c|c|}
\hline Soil Pit & $\begin{array}{l}\text { Estimated Soil Age in 1,000s of years } \\
\qquad(\mathrm{ka})\end{array}$ & Location \\
\hline BOR 15 & 1 to 3 & $\begin{array}{l}\text { Midway between the Big Lost River } \\
\text { and Site } 34\end{array}$ \\
\hline BOR 16 & 15 to 30 & North of Site 34 \\
\hline BOR 14 & 1 to 3 & West of the Big Lost River \\
\hline BOR 11 & 11 & $\begin{array}{l}\text { Between BOR } 10 \text { and the Big Lost } \\
\text { River }\end{array}$ \\
\hline BOR 9 & 10 to 30 & South of Site 5 \\
\hline BOR 10 & 15 to 50 & East of Site 5 \\
\hline
\end{tabular}

Bed shear stresses for the 20,000-year, 416-cms (at the INL Diversion Dam), natural-uncontrolled flood were shown in Figure 13. Shear stresses corresponding to a flow rate of 1,902 cms (at the INL Diversion Dam) are shown in Figure 20. The 1,902 cms-flow is comparable to the PMF flow (2,035 cms) predicted by Koslow and Van Haaften (1986). Therefore, shear stresses shown in Figure 20 would be comparable to those for the Mackay Dam failure PMF. Shear stresses for the seismically and piping-induced Mackay Dam failure cases would be lower. The peak values shown in Figure 20 are not cohesive or laterally continuous near either of the proposed facility locations. On the average, they are in the 5 to $25 \mathrm{~N} / \mathrm{m}^{2}$ range, which could cause erosion of upper terrace deposits and surface soils (see 
Figure 12). However, they are still much lower than the bed shear stresses required to cause significant geomorphic changes near the facilities.

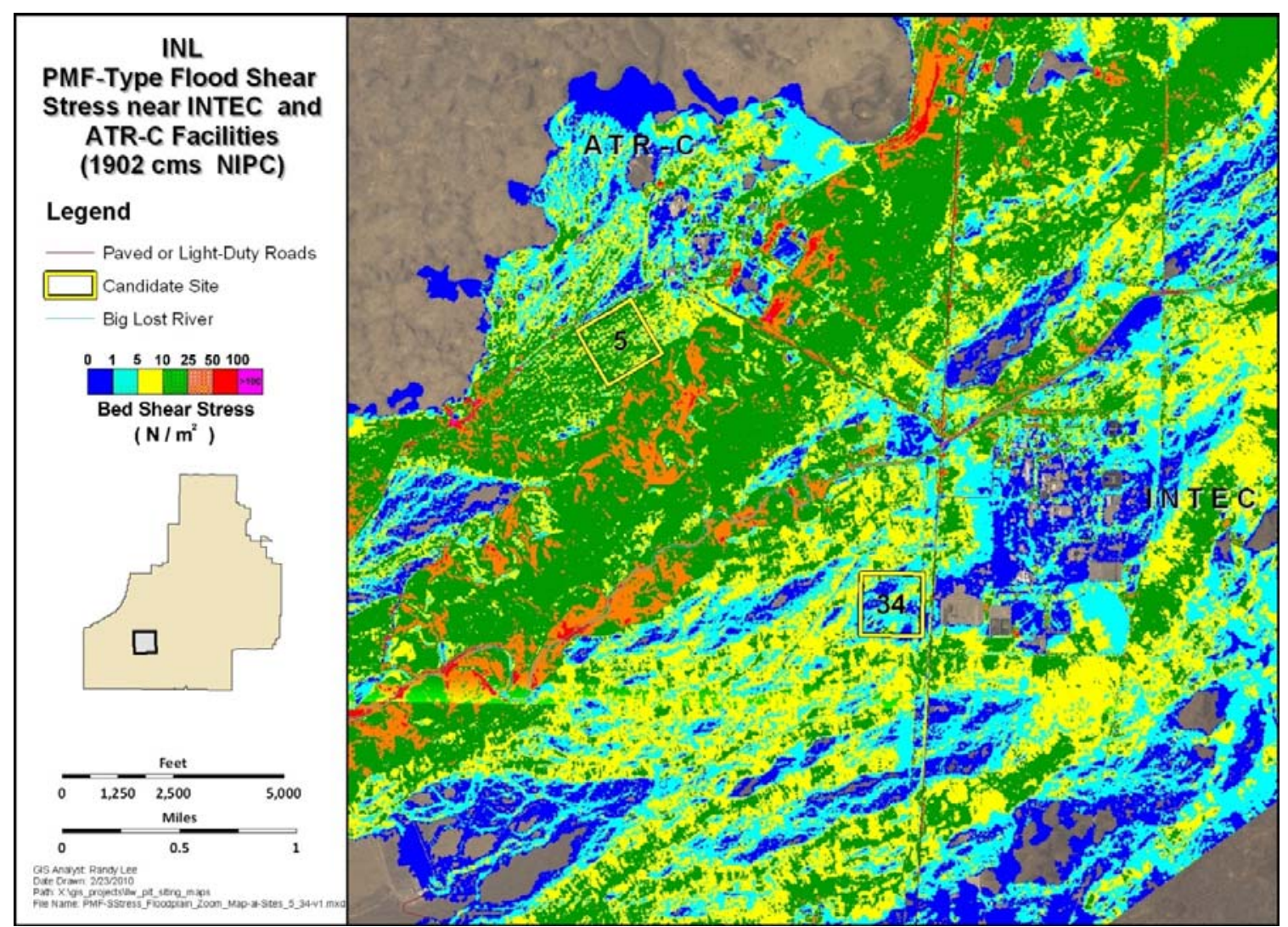

Figure 20. Bed shear stress near Idaho Nuclear Technology and Engineering Center and Advanced Test Reactor Complex facilities for the 1,902-cms flow rate at the INL Diversion Dam. This flow is approximately equal to the probably maximum flood flow of Koslow and Van Haaften (1986) and, under natural conditions, represents greater than 100,000-year flood. Figure adapted from Ostenaa and O’Connell (2005).

From a facility design and operations perspective, the erosion potential has the following limited impacts:

- During the operational period (0 to 50 years), erosion potential will be highest during the local extreme onsite precipitation event of 9 in. per hour. However, during this period, erosion would be controlled by onsite personnel and would not be expected to adversely impact the concrete vaults or their steel liners. At best, it might be expected that the sand infill between the concrete vaults surrounding soils would undergo an additional level of compaction. If a berm is emplaced around the facility during this time period, any erosion would be mitigated by operations.

- During the compliance period (50 to 1,000 years), it is highly unlikely that shear stresses during overland flow will exceed those predicted by the 1,902-cms flood model. These shear stresses could be sufficient to affect the natural near-surface ground sediments comprising the Snake River Plain. However, the shear stresses are insufficient to cause significant degradation to the cap given the design features of the cap. 
- During the post-compliance period, beyond 1,000 years, the worst case scenario is again presented by the PMF, assuming Mackay Dam remains in a similar configuration. Other scenarios present lower erosion potential. During this period, it is assumed that the engineered barrier is subject to erosion and the waste acceptance criteria and performance predictions account for this.

\subsection{Duration of Onsite Water and Recurrence}

The longer surface water is onsite and the frequency with which it appears can affect barrier erosion and subsurface transport of radionuclides. Mackay Dam failure in conjunction with the PMF represents the worst-case scenario for onsite water. As shown in Figure 16, the precursor precipitation resulted in discharge rates just downstream of Mackay Dam of $651 \mathrm{cms}$ (23,000 cfs) (0 hour Figure 16). During the outflow of water from the dam, the peak rate increased to 8,496 cms (300,000 cfs). Within 20 hours after complete dam failure, the in-channel flow rate had receded to pre-breach rates.

At the INL Diversion Dam, in-channel discharge rates did not reflect the upstream precipitation caused by the pre-cursor combined storm events. Within 10 hours of the dam breach, water arrived at the INL Diversion Dam, and within 12 hours, discharges reached their peak value (see Figure 16). In the simulation results presented by Koslow and Van Haaften (1986), the dam failed before the end of the PMP. This resulted in downstream discharge rates at the INL Diversion Dam remaining equal to the precursor in-channel rates just downstream of Mackay Dam. The simulation was not carried out to the point where discharge rates at the INL Diversion Dam reverted back to no-flow conditions, but it is likely that they would revert back to natural no-flow conditions within days based on the time-delay from Mackay Dam for first wave arrival and the overall storm duration.

For perspective, based on the simulations of Ostenaa and O'Connell (2005), the 10,000-year rate of $279 \mathrm{cms}(9,853 \mathrm{cfs})$ predicted very little surface water at the two candidate sites. However, the Ostenaa and O'Connell (2005) model assumed initially dry channels. Given the initial presence of onsite water from the PMF, it is likely that some water would reach the proposed sites with the 10,000-year flood rates, but it is unlikely that surface water would remain at the 5,000-year discharges rates. At the rate of decline south of Mackay Dam, the duration of onsite water would be likely less than 60 hours post-storm event.

Return periods for significant onsite water exceed 10,000 $\left(1.0 \times 10^{4}\right)$ years for natural flow scenarios (see Figure 11). The estimated AEP for the dam failure scenarios concurrent with natural precipitation events lead to return periods ranging between $1.5 \times 10^{5}$ and $4.5 \times 10^{8}$ years. The most likely event is the dam failure coincident with the 100-year flood, and the least likely event corresponds to the seismic and PMF scenarios. This implies that it is unlikely to have water at either site within the next 10,000 years under any condition.

\subsection{Subsurface Underflow Induced by Onsite Water}

\subsubsection{Background Information}

Infiltration of water into soils, and in particular, through the waste is determined by the hydraulic head (depth) and duration of flood water inundation. Infiltrating water has the potential of increasing in situ water velocities, thus increasing the release rate from resins and decreasing the residence time of radionuclides while in the vadose zone.

During the 2016 through 2065 operational period, the containers and vaults will provide sufficient barriers from water and air such that negligible transport of contaminants into the environment can occur. At the end of the operational period, the disposal facility will be covered with an engineered barrier (cover). The engineered cover should be designed to withstand wind and precipitation erosion for 1,000 years. To accomplish this, the cover should extend well beyond the boundary of the containers, originate with a height sufficient to withstand the effects of erosion, and be constructed of materials robust enough to withstand erosion. 
In addition, the cover will likely include features designed to minimize infiltration into the disposal facility. With the cover in place, water infiltration rates into the facility will dictate the contaminant leaching rates from the facility into the vadose zone immediately below the facility. The estimated infiltration rates through the ICDF cover are on the order of $1 \mathrm{~mm} / \mathrm{year}$, by design. This is a fraction of the $1 \mathrm{~cm} /$ year infiltration rate for undisturbed surficial sediments (Cecil et al. 1992). The contaminant migration rate is less than the infiltration rate and depends on the specific radionuclide.

The relative ratio of contaminant-to-water velocity is given by the retardation rate. The simplest and most common method of estimating contaminant retardation is based on the partition (or distribution) coefficient, $K_{d}$. The $K_{d}$ parameter is a factor related to the partitioning of a contaminant between the solid and aqueous phases. It is defined as the ratio of the quantity of the adsorbate adsorbed per mass of solid to the amount of the adsorbate remaining in solution at equilibrium. Chemical retardation, $R$, is defined as,

$$
\begin{aligned}
R= & \frac{v_{p}}{v_{c}} \\
& \text { where: } \quad v_{p}=\text { velocity of the water } \\
& v_{c}=\text { velocity of the contaminant. }
\end{aligned}
$$

In terms of the $K_{d}$, media bulk density $\left(\rho_{b}\right)$, and porosity $(\phi), R$ is defined as:

$$
R=1+\frac{\rho_{b} K_{d}}{\phi} \text {. }
$$

\subsubsection{Evaluation of Net Water Resulting from Flooding Scenarios versus Natural Conditions}

The average background precipitation rate at INL is about $22 \mathrm{~cm} /$ year. Evaporation and plant transpiration reduces the net infiltration to about $1 \mathrm{~cm} /$ year in undisturbed soils and to about $10 \mathrm{~cm} /$ year in disturbed soils. The net change in infiltrated water caused by periodic flooding is compared to that occurring during natural conditions. To make this comparison, a periodic 500-year flooding scenario with Mackay Dam failure is considered where a surface water depth of $50 \mathrm{~cm}$ results. This case presents a worse-case scenario because it requires that the dam be rebuilt every 500 years, and that a 500 -year flood happens in that time-period. Probability of the 500 -year flood occurring in 500 -years is only $63 \%$. The probability of the dam being rebuilt at the same height and location is unlikely.

As shown in Table 4, there is no net increase in water volume (or velocity) for the first 500 years. After the first flooding cycle, the recurrent nature of this hypothesized event increases the net volume by a constant $10 \%$. Relative to the overall uncertainty of predicting subsurface transport processes, climatic conditions, geologic conditions, and long-term hydrologic processes, the $10 \%$ increase in velocity is quite small. 
Table 4. Net volume of water per unit of cross-sectional area for natural and 500-year flood conditions.

\begin{tabular}{cccc}
\hline $\begin{array}{c}\text { Years after } \\
\text { facility } \\
\text { closure }\end{array}$ & $\begin{array}{c}\text { Cumulative net infiltration } \\
\text { from natural precipitation } \\
(\mathrm{m})\end{array}$ & $\begin{array}{c}\text { Cumulative infiltration of } 50 \mathrm{~cm} \\
\text { flood water every } 500 \text { years } \\
(\mathrm{m})\end{array}$ & $\begin{array}{c}\text { Flood water as a } \\
\text { percentage of net natural } \\
\text { precipitation infiltration }\end{array}$ \\
\hline 0 & 0 & 0 & 0 \\
100 & 1 & 0 & 0 \\
500 & 5 & 0.5 & $110 \%$ \\
1,000 & 10 & 1 & $110 \%$ \\
5,000 & 50 & 5 & $110 \%$ \\
10,000 & 100 & 10 & $110 \%$ \\
50,000 & 500 & 50 & $110 \%$ \\
100,000 & 1,000 & 100 & $110 \%$ \\
\hline
\end{tabular}

\subsubsection{Expected Transport and Flood Water Interaction}

The relative impact of flood water on contaminant transport is a function of contaminant-specific partition coefficient and radioactive half-life. Contaminants with high adsorption potential are unlikely to be mobilized under a flooding scenario during the 1,000-year institutional control period. This is primarily because the higher adsorption potential will allow them to be retained closer to the facility. This will reduce the propensity for these contaminants to come into contact with flood water intruding from the facility perimeter. It is more likely that flood waters will increase the mobility of contaminants with low sorption potential because it is more likely that they will be lower in the soil column at the onset of flooding. As classes of contaminants, the following relative impacts are expected:

- Low retardation, short half-life - Marginally retarded radionuclides with short-half lives will be most affected by short-term, sporadic occurrences of increased flood-induced pore water. These contaminants tend to move roughly with the speed of pore water. Higher velocities will reduce the residence time in the vadose zone, allowing them to reach the aquifer in fewer half-lives. This will increase the peak mass-flux, and thus, will increase aquifer concentrations for short time periods. It is unlikely that this increase will be offset by increased dilution caused by the additional flood water, primarily because of the short-flood-duration relative to the 0 to 3,000-year vadose zone travel time.

- Low retardation, long half-life - Radionuclides with long-half lives and low distribution coefficient also will be transported more quickly with the increased velocity. Because of long-half lives, there will not be an appreciable difference in net decay enroute. As with short half-life constituents, it is unlikely that the flood water will appreciably dilute concentrations because of the short, about 30-day flood length versus the 0 to 3000-year time for these radionuclides to traverse the vadose zone.

- High retardation - Highly retarded contaminants are difficult to mobilize under any conditions. During the first 1,000 years after closure of the proposed RH-LLW disposal facility, the cover will allow limited infiltration into the waste. High sorption, high retardation, and very slow moving infiltration water will limit the depth these contaminants can be transported during the performance period. Surface flood water migration will be gravity dominated, sending most of the flood water vertically downward. Lateral migration of the flood water will occur as a result of subsurface heterogeneity and capillary forces, but the opportunities for this to occur directly under the facility are limited. During the post-compliance period, these radionuclides will have migrated further into the vadose zone and will be more susceptible to transport. However, the net rate of mass flux of these contaminants will still be low because of sorption. Given the net difference in water volume for natural flow versus that for flooding scenarios, compared to the overall travel time of these 
contaminants, the resultant aquifer concentrations will be controlled by natural flow velocities. The influence of flooding will be invariant with respect to half-life.

\subsubsection{Simulated Transport and Flood Water Interaction}

The impacts of a flood at the proposed RH-LLW site were simulated using the one-dimensional unsaturated flow and transport model MCM (Rood 2005). The vadose-zone lithology for the simulation was taken from the ICDF Performance Assessment (DOE-ID 2010), which is representative of both proposed sites for the purposes of illustration (Table 5). Hydrological parameters are taken from Cahn et al. (2006) for alluvium, interbeds, and basalt.

Table 5. Lithology description for flooding scenario analysis.

\begin{tabular}{ccl}
\hline $\begin{array}{c}\text { Depth of top } \\
(\mathrm{m})\end{array}$ & $\begin{array}{c}\text { Depth of bottom } \\
(\mathrm{m})\end{array}$ & \multicolumn{1}{c}{ Lithology } \\
\hline 0 & 7.5 & Alluvium \\
7.5 & 24.78 & Basalt \\
24.78 & 26.32 & High permeability interbed \\
26.32 & 41.55 & Basalt \\
41.55 & 43.09 & High permeability interbed \\
43.09 & 59.83 & Basalt \\
59.83 & 65.93 & Low permeability interbed \\
65.93 & 93.362 & Basalt \\
93.362 & 96.41 & High permeability interbed \\
96.41 & 111.65 & Basalt \\
111.65 & 114.7 & Low permeability interbed \\
114.7 & 117.75 & High permeability interbed \\
117.75 & 138.47 & Basalt \\
\hline
\end{tabular}

The flooding scenario evaluated is an overly conservative implementation of the Mackay Dam failure scenario concurrent with the 500-year flood. In this case, the maximum onsite water depth is approximately $50 \mathrm{~cm}$, with an onsite duration of less than 30.5 days. The AEP for the combined 500-year flood and Mackay Dam piping failure event is $3.6 \times 10^{-7}\left(2.8 \times 10^{6}\right.$ year return period). For the purposes of illustration, we assume the facility to flood every 500 years, or 5,600 times more frequently that suggested by the annual return interval.

In keeping with the design of the proposed RH-LLW facility, the simulation assumed waste to be uniformly distributed within the upper $6 \mathrm{~m}$ of alluvium. Background infiltration is assumed to pass through the waste at $1 \mathrm{~cm} /$ year as allowed by the barrier. Leaching from the upper $6 \mathrm{~m}$ is controlled by contaminant-specific distribution coefficients and the background $1 \mathrm{~cm} /$ year infiltration rate (Cecil et al. 1992).

During the flood, we assume an additional $50 \mathrm{~cm}$ of flood water to infiltrate below the waste every 500 years for up to 4,500 years following closure of the facility. To simulate the arrival of flood water, it was assumed that the total infiltration rate increased linearly from the background rate of $1 \mathrm{~cm} /$ year to $6 \mathrm{~m} /$ year over a 30.5-day period and that it returned to background rate linearly over the next 30.5 days. The integrated water flux over this period was $50 \mathrm{~cm}$. This scenario allows water to infiltrate below the waste and to influence the water and contaminant fluxes throughout the remaining vadose zone but does not allow flood water to impact leaching from the waste. 
Transport of three hypothetical radionuclides with alluvium/interbed distribution coefficient values of $0 \mathrm{~mL} / \mathrm{g}, 2 \mathrm{~mL} / \mathrm{g}$, and $6 \mathrm{~mL} / \mathrm{g}$ were simulated. Basalt distribution coefficient values were assumed to be zero in all cases. Decay was not a factor as each radionuclide was assigned a half-life in excess of $1 \times 10^{9}$ years. The simulation was performed in two steps. In the first step, radionuclide fluxes to the aquifer were calculated for a background steady-state infiltration rate of $1 \mathrm{~cm} /$ year. The radionuclide fluxes at the base of the 6-m waste zone were extracted and used as an exogenous source for the second case that considered the flood. In the flood simulation, the first $6 \mathrm{~m}$ of the domain were omitted. The top boundary condition for water and radionuclide flux was equal to the background plus the additional $50 \mathrm{~cm}$ every 500 years for the flow simulation and the radionuclide flux at $6 \mathrm{~m}$ as given by the background simulation for the transport simulation.

Figure 21 shows water flux at the top of the domain and estimated water flux at the base (vadose zone-aquifer interface) of the domain. Figures 22 through 24 show the radionuclide flux at the vadose zone-aquifer interface for the three hypothetical radionuclides with different distribution coefficient values. The peak radionuclide flux into the aquifer for the $K_{d}=0$ (low retardation) case was about a factor of three greater than the peak flux for the background infiltration rate for a very short period of time. For radionuclides with distribution coefficient values of 2 and $6 \mathrm{~mL} / \mathrm{g}$, peak radionuclide fluxes into the aquifer did not increase, but at selected times, before the peak, the radionuclide fluxes into the aquifer were about a factor of 5 higher than the background flux value.

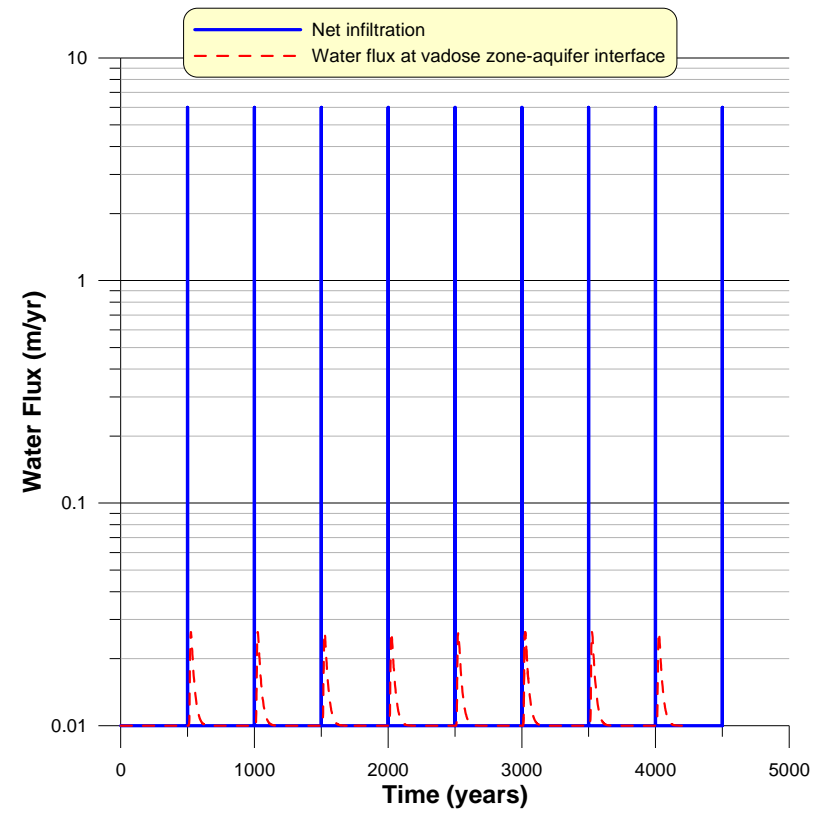

Figure 21. Net infiltration water flux below the waste and water flux at the vadose zone-aquifer interface. 


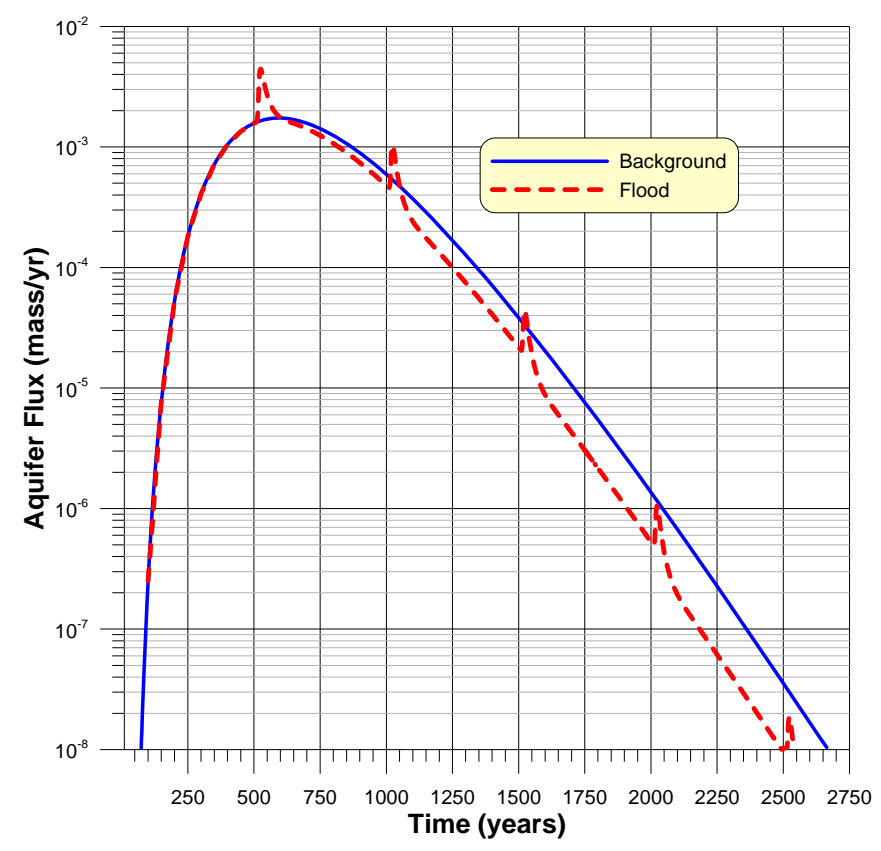

Figure 22. Radionuclide flux as a function of time at the vadose zone-aquifer interface for a radionuclide with a distribution coefficient of zero $\mathrm{mL} / \mathrm{g}$.

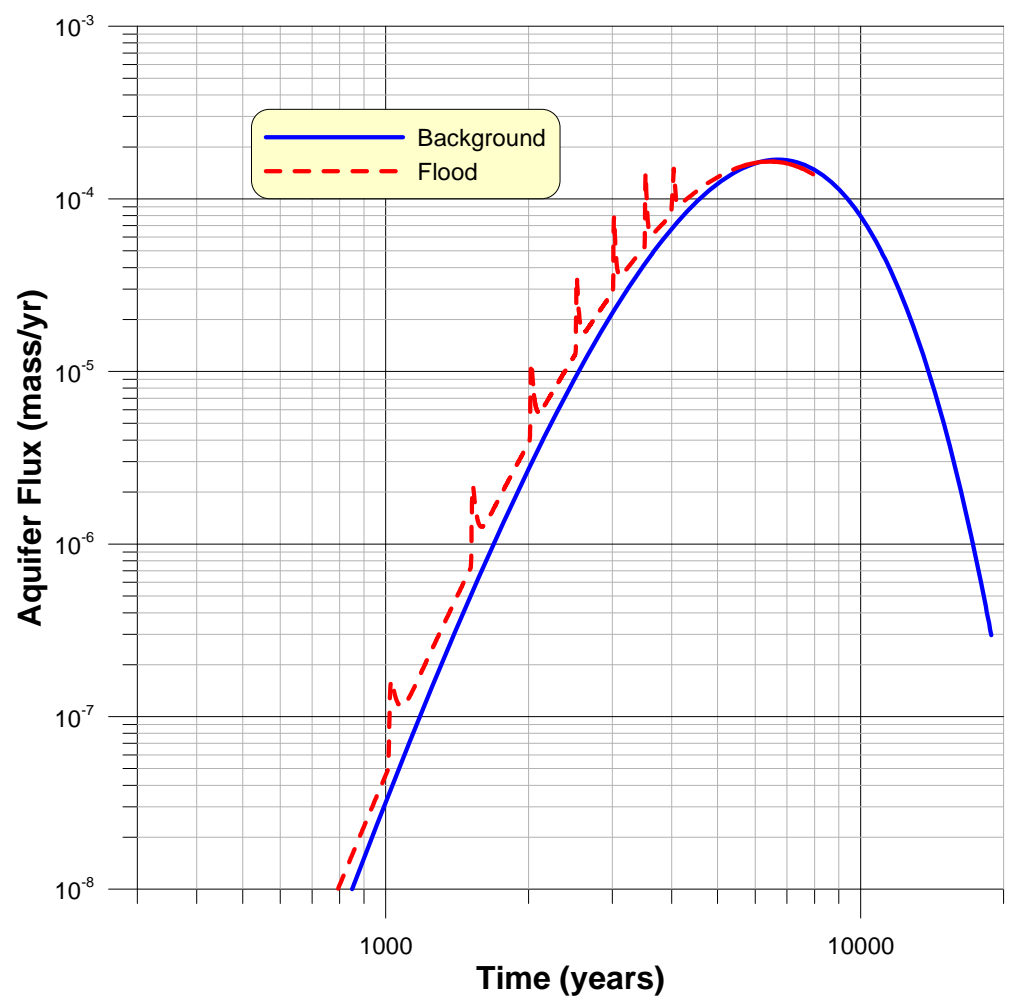

Figure 23. Radionuclide flux as a function of time at the vadose zone-aquifer interface for a radionuclide with a distribution coefficient of $2 \mathrm{~mL} / \mathrm{g}$. 


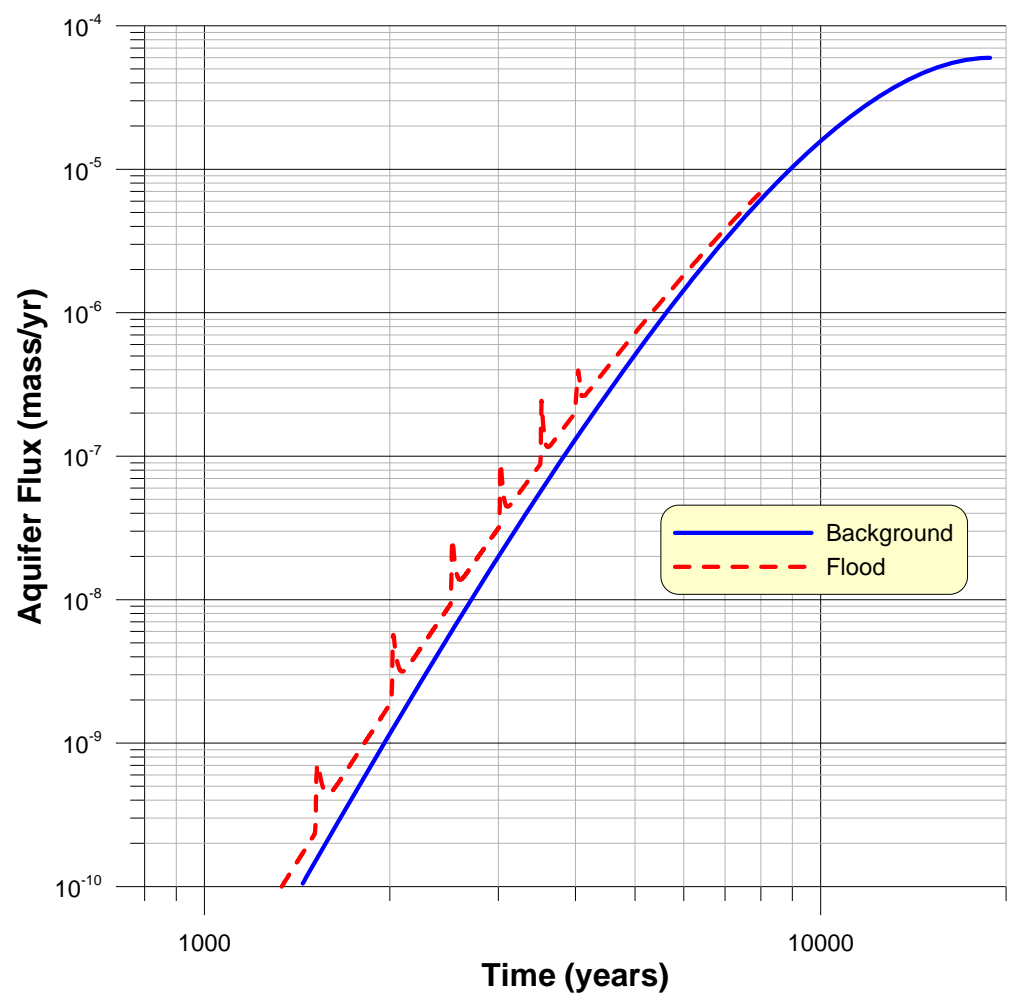

Figure 24. Radionuclide flux as a function of time at the vadose zone-aquifer interface for a radionuclide with a distribution coefficient of $6 \mathrm{~mL} / \mathrm{g}$.

\section{CONCLUSION}

The likelihood of detrimental flood water impacting either of the proposed RH-LLW facility sites is extremely low. The AEP associated with uncontrolled flows in the Big Lost River impacting either of the proposed sites is $1 \times 10^{-5}$, corresponding to a return period of 10,000 years. The most probable dam failure scenario has an AEP of $6.3 \times 10^{-6}$ and a return period of $1.6 \times 10^{5}$ years. In any of the scenarios generating possible onsite water, the duration is expected to be quite short, water depths are not expected to exceed $0.5 \mathrm{~m}$, and the erosion potential can easily be mitigated by emplacement of a berm (operational period) and an engineered cover (post-closure period).

Subsurface mobilization of radionuclides was evaluated for a very conservative flooding scenario. The flooding evaluation assumed Mackay Dam failure concurrent with a 500-year flood. In this case, the maximum onsite water depth is approximately $50 \mathrm{~cm}$, with an onsite duration of less than 30.5 days. The AEP for the piping failure of Mackay Dam coincident with a 500-year flood is $3.6 \times 10^{-7}\left(2.8 \times 10^{6}\right.$ year return period). For the purposes of illustration, the facility was flooded every 500 years. The periodically recurring flood waters were predicted to marginally increase peak radionuclide fluxes into the aquifer by about a maximum factor of three for nonsorbing radionuclides and have limited impact on peak radionuclide fluxes into the aquifer for contaminants that do sorb. 


\section{REFERENCES}

42 USC § 4321 et seq., “National Environmental Policy Act of 1969 (NEPA),” United States Code, January 1970.

ANS 2.8, 1977, American National Standard N170-1976. Standards for Determining Design Basis Flooding at Power Reactor Sites. Prepared and published by the American Nuclear Society, Hinsdale, Illinois.

ANS 2.8, 1992, Determining Design Basis Flooding at Power Reactor Sites, American Nuclear Society Report ANSI/ANS-2.8-1992, published by the American Nuclear Society, LaGrange Park, Illinois.

Bennett, C. M., 1986, “Capacity of the Diversion Channel Below the Flood-Control Dam on the Big Lost River at the Idaho National Engineering Laboratory, Idaho:” U.S. Geological Survey WaterResources Investigations Report 86-4204, Idaho Falls, ID.

Berenbrock, C., and L. C. Kjelstrom, 1998, "Preliminary Water-Surface Elevations and Boundary of the 100-Year Peak Flow in the Big Lost River at the Idaho National Engineering and Environmental Laboratory, Idaho:” U.S. Geological Survey Water-Resources Investigations Report 98-4065, Idaho Falls, ID.

Berenbrock, C., J. P Rousseau, and B. V. Twining, 2007, "Hydraulic Characteristics of Bedrock Constrictions and an Evaluation of One- and Two-Dimensional Models of Flood Flow on the Big Lost River at the Idaho National Engineering and Environmental Laboratory, Idaho:” U.S. Geological Survey Scientific Investigations Report 2007-5080 (DOE/ID-22194), Idaho Falls, ID.

Cahn, L., M. Abbott, J. Keck, P. Martian, A. Schafer, and M. Swenson, 2006, Operable Unit 3-14 Tank Farm Soil and Groundwater Remedial Investigation/Baseline Risk Assessment, DOE/NE-ID-11227, Rev. 0, U.S. Department of Energy Idaho Operations Office, Idaho Falls, ID, April 2006.

Carrigan, P. H., Jr., 1972, "Probability of Exceeding Capacity of Flood-Control Systems at the National Reactor Testing Station, Idaho:” U.S. Geological Survey Open-File Report (IDO-22052), Idaho Falls, Id.

Cecil, L. D., J. R. Pittman, T. M. Beasley, R. L. Michel, P. W. Kubik, P. Sharma, U. Fehn, and H. Gove, 1992, "Water Infiltration Rates in the Unsaturated Zone at the Idaho National Engineering Laboratory Estimated by Chlorine-36 and Tritium Profiles, and Neutron Logging," in Proceedings of the $7^{\text {th }}$ International Symposium on Water-Rock Interactions, WRI-7, Y. K. Kharaka and A. S. Meest, eds., Park City, Utah, July 13-18, 1992.

Costa, J. E., 1978, “Holocene Stratigraphy in Flood Frequency Analysis,” Water Resources Research, Vol 14: 626-632.

DOE Order 435.1, Change 1, 2001, “Radioactive Waste Management,” U.S. Department of Energy, August 28, 2001.

DOE-ID, 2010, Performance Assessment for the INEEL CERCLA Disposal Facility Landfill, DOE/ID-10978, Rev. 1 (DRAFT), U.S. Department of Energy Idaho Operations Office, Idaho Falls, ID. 
Downs, W. A., W. Miller, J. Bledsoe, E. J. Nelson, M. Radaideh, and C. Smemoe, 1999, "Probabilistic Hydrologic Modeling for the Proposed High Level Waste Treatment Facility at the Idaho National Engineering and Environmental Laboratory,” Part 2-Hydraulic Routing: Brigham Young University, Department of Civil and Environmental Engineering.

Druffel, L., G. J. Stiltner, and T. N. Keefer, 1979, "Probable Hydrologic Effects of a Hypothetical Failure of Mackay Dam on the Big Lost River Valley from Mackay, Idaho, to the Idaho National Engineering Laboratory:” U.S. Geological Survey Water-Resources Investigation Report 79-99.

Hansen, E. M., D. D. Fenn, P. Corrigan, J. L. Vogel, L. C. Shreiner, and R. W. Stodt, 1994, Probable Maximum Precipitation - Pacific Northwest States, Columbia River (including Portions of Canada), Snake River and Pacific Coastal Drainages, Hydrometeorological Report No. 57, Published by National Weather Service, Silver Spring, MD.

Harvego, L., B. Orchard, A. Conner, J. Connolly, M. Hinman, C. Marcinkiewicz, and G. Mecham, 2009, Conceptual Design Report for the Remote Handled Low-Level Waste Disposal Facility, INL/EXT-07-12901, Rev. 1, Idaho National Laboratory, October 2009.

Harvego, L., J. Connolly, L. Peterson, B. Orr, and B. Starr, 2010, Siting Study for the Remote-Handled Low-Level Waste Disposal Facility, INL/EXT-07-12902, Idaho National Laboratory, January 2010.

Holdren, K. J., T. E. Bechtold, and B. D. Preussner, 2007, Feasibility Study for Operable Unit 7-13/14, DOE/ID-11268, Rev. 0, U.S. Department of Energy Idaho Operations Office.

Hortness, J. E. and J. P. Rousseau, 2003, Estimating the Magnitude of the 100-Year Peak Flow in the Big Lost River at the Idaho National Engineering and Environmental Laboratory, Idaho, U.S. Geological Survey Water Resources Investigations Report 02-4299, (DOE/ID-22181) Idaho Falls, Idaho.

INEL, 1996, Site-Specific Probabilistic Seismic Hazard Analyses for the Idaho National Engineering Laboratory, Volume 1, Final Report, INEL-95/0536, Idaho National Engineering Laboratory, May 1996.

Interagency Advisory Committee on Water Data, 1982, "Guidelines for Determining Flood Flow Frequency,” Bulletin \#17B of the Hydrology Subcommittee: Reston, Va., U.S. Geological Survey, Office of Water Data Coordination.

Kjelstrom, L. C., 1991, “Idaho, Floods and Droughts,” in Paulson, R. W., Chase, E. B., Roberts, R. S., and Moody, D. W., National Water Summary 1988-89 - Hydrologic Events and Floods and Droughts: U.S. Geological Survey Water-Supply Paper 2375, p. 255-262.

Kjelstrom, L.C. and C. Berenbrock, 1996, Estimated 100-year peak flows and flow volumes in the Big Lost River and Birch Creek at the Idaho National Engineering Laboratory, Idaho: U.S. Geological Survey Water-Resources Investigations Report 96-4163, Idaho Falls, ID.

Koslow, K. N. and D. H. Van Haaften, 1986, Flood Routing Analysis for a Failure of Mackay Dam, EGG-EP-7184, Idaho National Engineering Laboratory, Idaho Falls, ID.

Noble, C., 1980, A Two-Dimensional Analysis of Flooding of the Big Lost River Below Box Canyon Outlet, EI-80-2, Energy Incorporated, Idaho Falls, ID, January 1980. 
Ostenaa, D. A., D. R. Levish, R. E. Klinger, and D. R. H. O’Connell, 1999, Phase 2 Paleohydrologic and Geomorphic Studies for the Assessment of Flood Risk for the Idaho National Engineering and Environmental Laboratory, Idaho, Report 99-7, Geophysics, Paleohydrology, and Seismotectonics Group, Technical Service Center, U.S. Bureau of Reclamation, Denver, Colorado.

Ostenaa, D. A. and D. R. H. O’Connell, 2005, Big Lost River Flood Hazard Study Idaho National Laboratory, Idaho, Report 2005-2, Seismotectonics and Geophysic Group, Technical Service Center, U.S. Bureau of Reclamation, Denver, Colorado.

Rood, A. S., 2005, Mixing Cell Model: A One-Dimensional Numerical Model for Assessment of Water Flow and Contaminant Transport in the Unsaturated Zone, ICP/EXT-05-00748, Rev. 0, Idaho Completion Project, March 2005.

Sagendorf, J., 1996, "Precipitation Frequency and Intensity at the Idaho National Engineering Laboratory,” ARLFRD 94-100, U.S. Department of Commerce, National Oceanic Atmospheric Administration, Environmental Research Laboratories, Air Resources Laboratory Field Research Division, Idaho Falls, ID, 1996.

U.S. Army Corps of Engineers, 1967, Postflood Report, Flood of June-July 1967, Big Lost River, Idaho: Walla Walla, Washington, U.S. Army Corps of Engineers. 